\title{
Loss of $\mathrm{Na}^{+}$channel $\beta 2$ subunits is neuroprotective in a mouse model of Multiple Sclerosis
}

\author{
Heather A. O’Malley ${ }^{1}$, Andrew B. Shreiner ${ }^{2}$, Gwo-Hsiao Chen ${ }^{2}$, Gary B. Huffnagle ${ }^{2,3}$, and \\ Lori L. Isom ${ }^{1}$, \\ 1 Department of Pharmacology and Program in Cellular and Molecular Biology, University of Michigan, \\ Ann Arbor, MI 48109-0632 \\ 2 Pulmonary Division, Department of Internal Medicine and Program in Immunology, University of \\ Michigan, Ann Arbor, MI 48109-0642
}

3 Department of Microbiology and Immunology, University of Michigan, Ann Arbor, MI 48109-0642

\section{Abstract}

Multiple Sclerosis (MS) is a CNS disease that includes demyelination and axonal degeneration. Voltage-gated $\mathrm{Na}^{+}$channels are abnormally expressed and distributed in MS and its animal model, Experimental Allergic Encephalomyelitis (EAE). Up-regulation of $\mathrm{Na}^{+}$channels along demyelinated axons is proposed to lead to axonal loss in MS/EAE. We hypothesized that $\mathrm{Na}^{+}$channel $\beta 2$ subunits (encoded by $S c n 2 b$ ) are involved in MS/EAE pathogenesis, as $\beta 2$ is responsible for regulating levels of channel cell surface expression in neurons. We induced non-relapsing EAE in $S c n 2 b^{+/+}$and $S c n 2 b^{-1-}$ mice on the C57BL/6 background. Scn $2 b^{-/-}$mice display a dramatic reduction in EAE symptom severity and lethality as compared to wildtype, with significant decreases in axonal degeneration and axonal loss. Scn $2 b^{-1-}$ mice show normal peripheral immune cell populations, $\mathrm{T}$ cell proliferation, cytokine release, and immune cell infiltration into the CNS in response to EAE, suggesting that $S c n 2 b$ inactivation does not compromise immune function. Our data suggest that loss of $\beta 2$ is neuroprotective in EAE by prevention of $\mathrm{Na}^{+}$channel up-regulation in response to demyelination.

\section{INTRODUCTION}

Multiple Sclerosis (MS) is an autoimmune, inflammatory CNS disease characterized by demyelination and axonal degeneration (Dutta and Trapp, 2007). Patients experience multiple symptoms including muscle weakness or paralysis, impaired motor coordination, optic neuritis, and cognitive dysfunction. Following demyelination in MS, action potential conduction is significantly impaired or lost. A population of axons then recovers the ability to conduct action potentials in spite of myelin loss, contributing to clinical remission. In contrast, another population of axons degenerates in response to demyelination and this process has been implicated as the primary cause of permanent disability (reviewed in (Bechtold and Smith, 2005; Waxman, 2006)). Neuroprotection is a critical goal in the development of MS therapies;

*Corresponding Author: Department of Pharmacology, Program in Cellular and Molecular Biology, The University of Michigan, 1301 MSRB III, 0632, 1150 W. Medical Center Dr. Ann Arbor, MI 48109-0632, 734-936-3050, 734-763-4450 (fax), E-mail: lisom@umich.edu.

Publisher's Disclaimer: This is a PDF file of an unedited manuscript that has been accepted for publication. As a service to our customers we are providing this early version of the manuscript. The manuscript will undergo copyediting, typesetting, and review of the resulting proof before it is published in its final citable form. Please note that during the production process errors may be discovered which could affect the content, and all legal disclaimers that apply to the journal pertain. 
if axons are spared, strategies for the promotion of remyelination and restoration of saltatory conduction can then be initiated.

Evidence is accumulating that intra-axonal accumulation of $\mathrm{Na}^{+}$leading to $\mathrm{Ca}^{2+}$ overload plays a major role in neurodegenerative disease (reviewed in (Bechtold and Smith, 2005; Coleman, 2005; Frohman et al., 2005; Smith, 2007; Stys, 2005; Waxman, 2006)). Up-regulation and diffuse distribution of $\mathrm{Na}_{\mathrm{v}} 1.2$ along demyelinated axons is proposed to have beneficial effects, resulting in recovery from conduction block and clinical remission. However, up-regulation and diffuse distribution of $\mathrm{Na}_{\mathrm{v}} 1.6$ along demyelinated axons is proposed to lead to $\mathrm{Na}^{+}$influx mediated by persistent $\mathrm{Na}^{+}$current (Burbidge et al., 2002; Herzog et al., 2003; Rush et al., 2005; Smith et al., 1998), accumulation of intra-axonal $\mathrm{Na}^{+}$, activation of reverse $\mathrm{Na}^{+}-\mathrm{Ca}^{2+}$ exchange, accumulation of intra-axonal $\mathrm{Ca}^{2+}$, and activation of damaging injury cascades (Craner et al., 2004b; Waxman, 2008a, b; Waxman et al., 2004). Consistent with this, reductions in plasma membrane calcium ATPase isoform 2 (PMCA2) levels of activity lead to delays in neuronal $\mathrm{Ca}^{2+}$ clearance, neuronal damage, and axonal loss in spinal cord neuronal cultures (Kurnellas et al., 2005). In contrast, but also in agreement with this hypothesis, cyclophilin D null mice are neuroprotective in EAE because their mitochondria are able to more effectively handle elevated $\mathrm{Ca}^{2+}$ (Forte et al., 2007).

Other observations support the hypothesis that $\mathrm{Na}^{+}$influx through voltage-gated $\mathrm{Na}^{+}$channels plays a role in neurodegeneration. Nitric oxide, which is increased in MS lesions, increases the probability of $\mathrm{Na}^{+}$channel opening and thus increases the amplitude of persistent $\mathrm{Na}^{+}$current in neurons (Bielefeldt et al., 1999; Hammarstrom and Gage, 1999; Li et al., 1998; Rush et al., 2005). Low doses of $\mathrm{Na}^{+}$channel blocking agents such as phenytoin and flecanide are neuroprotective in EAE and MS (Bechtold et al., 2005; Besancon et al., 2008; Dave et al., 2001; Fern et al., 1993; Hains et al., 2004; Hemmings, 2004; Hewitt et al., 2001; Kapoor, 2008; Kaptanoglu et al., 2005; Lo et al., 2002; Lo et al., 2003; Sareen, 2002; Schwartz and Fehlings, 2001; Waxman, 2005, 2008b). In addition, pharmacological blockade of $\mathrm{Na}^{+}$ channels reduces secondary injury and increases recovery from trauma following experimental spinal cord injury (Kaptanoglu et al., 2005), results in protection of retinal ganglion cells and optic nerve axons in an experimental model of glaucoma (Hains and Waxman, 2005), and provides a neuroprotective effect in an animal model of hypoxic-ischemic encephalopathy (Papazisis et al., 2008), suggesting that blockade of persistent $\mathrm{Na}^{+}$current may be a general mechanism of neuroprotection.

Neuronal $\mathrm{Na}^{+}$channel up-regulation and/or redistribution following nerve injury or demyelination may have both beneficial and detrimental effects, leading not only to recovery from conduction block, but also to intra-axonal accumulation of $\mathrm{Na}^{+}$and the initiation of a cascade of signaling events that ultimately result in axonal degeneration and permanent disability (England et al., 1991; England et al., 1990; Moll et al., 1991; Westenbroek et al., 1992). These observations demonstrate that the regulation of cell surface expression and function of $\mathrm{Na}^{+}$channels in injured or demyelinated neurons is critical to neuronal survival and recovery in disease. A complete understanding of these processes is essential for the development of novel and more effective neuroprotective agents.

We showed previously that deletion of the $\mathrm{Na}^{+}$channel $\beta 2$ subunit (encoded by $S c n 2 b$ ) in mice results in reduced $\mathrm{Na}^{+}$channel cell surface expression with a corresponding decrease in $\mathrm{Na}^{+}$ current density in both CNS and PNS neurons (Chen et al., 2002; Lopez-Santiago et al., 2006). In the present study we sought to test the hypothesis that $\beta 2$ subunits play a role in axonal degeneration in demyelinating disease via control of $\mathrm{Na}^{+}$channel expression. We show that $\operatorname{Scn} 2 b^{-/-}$mice have attenuated symptoms and reduced axonal degeneration in an animal model of MS, Experimental Allergic Encephalomyelitis (EAE). Scn $2 b^{-1-}$ mice have normal inflammatory and immune responses in EAE, suggesting that the mechanism of 
neuroprotection in these animals is not immunomodulatory but is a direct effect on axons. Finally, we show that, while $\mathrm{Na}_{\mathrm{v}} 1.2$ and $\mathrm{Na}_{\mathrm{v}} 1.6$ are distributed similarly along demyelinated axons in wildtype and null mice, $\mathrm{Na}_{\mathrm{v}} 1.6$ protein expression, which is normally up-regulated in brain in EAE, is attenuated in $S c n 2 b^{-/-}$mice, suggesting that the level of $\mathrm{Na}_{\mathrm{v}} 1.6$ mediated current in the demyelinated regions of axons may be reduced compared to wildtype. We conclude that $\operatorname{Scn} 2 b$ plays a critical role in neurodegeneration and propose that $\mathrm{Na}^{+}$channel $\beta 2$ subunits may provide a novel target for future drug development in neuroprotection.

\section{RESULTS}

\section{Scn $2 b^{-/-}$mice display attenuated EAE symptom severity and lethality}

We induced EAE in $S c n 2 b^{+/+}$and $S c n 2 b^{-/-}$mice using myelin oligodendrocyte glycoprotein (MOG) $35-55$ peptide, an induction protocol that produces a chronic, non-remitting disease course in mice bred on the C57BL/6 genetic background (Chabas et al., 2001; McQualter et al., 2001). Scn $2 b^{+/+}$mice (Fig. 1A, filled squares) displayed a disease course in which symptoms began to present between days 10 to 15 post-injection and rapidly progressed beyond clinical stage 3 (corresponding to full hind limb paralysis), as assessed by daily scoring of clinical symptoms using a five-point grading system. In contrast, $S c n 2 b^{-/-}$mice (Fig. $1 \mathrm{~A}$, open squares) displayed a significantly less severe disease course, with symptoms also first appearing between days 10 to 15 post-injection, but with the disease course rarely progressing past clinical stage 2 (corresponding to hind limb weakness). Control animals of both genotypes, which received all parts of the EAE induction protocol with the exception of the $\mathrm{MOG}_{35-55}$ peptide, did not display clinical symptoms at any time during the experimental time course, up to 70 days post-injection (data not shown).

To account for the possibility that differences in observed clinical symptoms were due to alterations in the timing of symptom onset, rather than to an amelioration of symptom severity, data were also plotted as mean clinical score assessed at each day post-onset of symptoms (Fig. 1B). $S c n 2 b^{-1-}$ mice (open squares) displayed a consistent and significant reduction in disease severity compared to $S c n 2 b^{+/+}$mice (filled squares), consistent with observations made postinjection (Fig. 1A). Thus, a significant improvement in clinical symptom severity was observed in the absence of $\beta 2$, with no observable changes in the time of onset of the disease.

$\operatorname{Scn} 2 b^{-1-}$ mice displayed a significant reduction in EAE-induced lethality. We determined the percentage of mice able to develop at least stage 1 clinical symptoms (corresponding to a limp tail) and used this as an indication of the ability of $S c n 2 b^{-/-}$mice to develop EAE (Fig. 1C). Both genotypes were equally susceptible to the onset of EAE; nearly every mouse treated with the $\mathrm{MOG}_{35-55}$ peptide successfully reached at least clinical stage $1\left(96.9 \%\right.$ Scn $2 b^{+/+} v s .93 .1 \%$ $\operatorname{Scn} 2 b^{-1-}$ ). We then determined the percentage of mice reaching end stage during the experimental time course, with end stage defined as a moribund or dead animal. Only $16.7 \%$ of $S c n 2 b^{-/-}$mice reached end stage compared to $53.6 \%$ of $S c n 2 b^{+/+}$mice, representing a $31 \%$ decrease in EAE-induced lethality in the absence of $\beta 2$. This decrease in lethality was also apparent when survival data were plotted (Fig. 1D), showing a marked decrease in survival of $S c n 2 b^{+/+}$mice compared to $S c n 2 b^{-/-}$mice over time.

\section{Scn2 $b^{-/-}$mice display decreased axonal degeneration in EAE}

Axonal loss is a characteristic component of EAE and underlies the development of clinical symptoms (Bjartmar et al., 2003; Stys et al., 1992; Waxman, 2006). We used transmission electron microscopy (TEM) to evaluate the extent of axonal degeneration and axonal loss in $S c n 2 b^{+/+}$and $S c n 2 b^{-/-}$mice during EAE. We examined ultrathin cross-sections of optic nerve from all experimental groups (peptide and control) at 19 days post-injection (dpi) of the $\mathrm{MOG}_{35-55}$ peptide. At this time point, both genotypes displayed similar clinical symptoms 
(see Fig. 1A). A representative set of electron micrographs is shown (Fig. 2, A-D). To assess the extent of axonal loss, we quantified the total number of axons per field of view (FOV) in optic nerve cross-sections from each genotype (Fig. 2E). In control tissues of both genotypes, optic nerve sections showed normally myelinated, large, medium, and small axons (Stys et al., 1991). In EAE optic nerve, both genotypes exhibited axonal loss. Scn $2 b^{+/+}$optic nerves displayed a $24.0 \%$ decrease in total axon number/FOV during EAE (at 19 dpi) compared to control tissue at the same time point $(\mathrm{p}<0.0001)$. In contrast, $S c n 2 b^{-l-}$ EAE tissue displayed only a $6.2 \%$ decrease in axon number compared to control at this time point $(\mathrm{p}=0.0003)$. When total axon numbers/FOV in $S c n 2 b^{+/+}$and $S c n 2 b^{-/-}$optic nerves after EAE induction were compared, a significant difference was also observed, with $24.75 \%$ fewer axons in $S c n 2 b^{+/+}$ mice than $S c n 2 b^{-1-}$ ( $\left.\mathrm{p}<0.0001\right)$. There was a small but significant increase in total axon number/FOV in control tissue for $S c n 2 b^{-/-}$optic nerves compared to $\operatorname{Scn} 2 b^{+/+}(\mathrm{p}=0.0002)$, suggesting that absence of $\beta 2$ may decrease normal axonal loss during brain development.

We next quantified the number of axons that were in the process of degeneration for each genotype using the same set of TEM images (Fig. 2G). Control tissue contained few, if any, degenerating axons. In contrast, after EAE induction, nerves displayed axonal degeneration, as well as degeneration of the myelin sheath, characteristic of the disease. As expected, for both genotypes, there was a significant increase in the extent of degeneration in EAE tissue compared to control: a $456 \%$ increase in $S c n 2 b^{+/+}$and a $274 \%$ increase in $S c n 2 b^{-/-}$(p $<0.0001$ for both). Scn $2 b^{+/+}$optic nerve during EAE showed an average of 9.3 degenerating axons/ FOV, compared to 5.8 degenerating axons/FOV in $S c n 2 b^{-/-}$tissue, representing a 1.6-fold difference ( $\mathrm{p}<0.0001)$. We thus observed a greater extent of pathology in $S c n 2 b^{+/+}$tissue compared to $\operatorname{Scn} 2 b^{-1-}$, in spite of similar symptom severity in these mice at this time point (19 dpi). No differences were observed between groups of control nerves, showing that loss of $\beta 2$ does not induce axonal degeneration in the absence of disease.

We calculated the extent of axonal degeneration as a percentage of total axon number (Fig. $2 \mathrm{H}$ ); this value was obtained for each image independently and values were then averaged together for each genotype and condition. This measurement confirmed that observed differences in degeneration between genotypes were not due simply to the changes in total axon numbers in $S c n 2 b^{+/+} v s$. Scn $2 b^{-1-}$ mice post-EAE induction. Consistent with the results presented in Fig. 2B, we observed a significant difference in the percentage of axonal degeneration between genotypes at 19 dpi during EAE. $12.15 \%$ of $S c n 2 b^{+/+}$nerves were determined to be undergoing degeneration, compared to $5.34 \%$ of $S c n 2 b^{-l-}$ nerves; this represents a $228 \%$ difference $(\mathrm{p}<0.0001)$. There was also a significant increase in the level of degenerating axons after EAE induction in each genotype as compared to control: $623 \%$ for $S c n 2 b^{+/+}$and $286 \%$ for $S c n 2 b^{-l-}$ ( $\mathrm{p}<0.0001$ for both). No differences were observed between control groups.

Finally, we calculated the percent of axons that were demyelinated or thinly myelinated (defined by zero, one, or two myelin wraps) in optic nerves of $\operatorname{Scn} 2 b^{+/+} v s . S c n 2 b^{-/-}$mice at 19 dpi (Fig. 2F). We observed an increase in the percentage of demyelinated or thinly myelinated axons in both genotypes following EAE induction compared to control conditions ( $\mathrm{p}<0.0001$ for both genotypes). Comparing genotypes, we observed a difference in the percentage of demyelinated or thinly myelinated axons in EAE: $5.8 \%$ of $S c n 2 b^{+/+}$vs. $3.9 \%$ of $\operatorname{Scn} 2 b^{-1-}$ axons $(\mathrm{p}<0.0001)$.

\section{Scn2 $b^{-/-}$mice exhibit normal inflammatory and immune responses to $\mathrm{MOG}_{35-55}$ peptide}

To develop symptoms of EAE, animals must be able to successfully mount an inflammatory immune response to the presence of MOG antigen. Critical mediators of this response include pro-inflammatory cytokines and activated T cells. A possible explanation for the decreased EAE pathology observed in $S c n 2 b^{-1-}$ animals is that $S c n 2 b$ deletion results in an impaired 
immune response. To test this possibility, we performed experiments to assess the ability of $S c n 2 b^{-1-}$ animals to mount an inflammatory immune response to the $\mathrm{MOG}_{35-55}$ peptide.

Fluorescence-activated cell sorting techniques were used to assess populations of peripheral immune cells in naïve mice and mice induced with the EAE protocol for both genotypes (Fig. 3). Animals were sacrificed at $12 \mathrm{dpi}$ and splenocytes isolated for immediate analysis. In EAE animals, spleens from both wildtype and null animals were significantly enlarged, as assessed by visual observation, compared to spleens from animals not exposed to the $\mathrm{MOG}_{35-55}$ peptide (data not shown). We used cell surface markers to quantify populations of dendritic cells (CD11c), B cells (CD19) and T cells (CD4 and CD8a). Cells obtained from naïve animals showed similar population distributions of each of these cell types for both genotypes (Fig. $3 \mathrm{~A}$ ), indicating that resting numbers of peripheral immune cells in the absence of antigen are not altered as a result of $S c n 2 b$ deletion. Importantly, cells obtained after EAE induction also showed similar distributions between wildtype and null mice (Fig. 3B). Finally, we used Western blot analysis to determine whether splenocytes express $\mathrm{Na}^{+}$channel $\alpha$ or $\beta 2$ proteins, either under naïve conditions or after EAE induction. As shown in Fig. 3C and Fig. 3D, no immunoreactive $\beta 2$ or $\mathrm{Na}^{+}$channel bands $\left(\mathrm{Na}_{\mathrm{v}} 1.1, \mathrm{Na}_{\mathrm{v}} 1.2\right.$, or $\left.\mathrm{Na}_{\mathrm{v}} 1.6\right)$, respectively, were detected in splenocyte lysates, in contrast to brain membranes. Thus, loss of $\beta 2$ does not measurably affect peripheral immune cell populations, either under control conditions or in the presence of antigen during an inflammatory immune response.

The inflammatory response to MOG in vivo may be modulated by cytokine release. We therefore examined the ability of splenocytes from $S c n 2 b^{+/+}$and $S c n 2 b^{-/-}$animals induced with EAE to release cytokines in vitro in response to the presence of $\mathrm{MOG}_{35-55}$ peptide. We used ELISA to quantify levels of cytokine release (Fig. 3E). We monitored IFN- $\gamma$ to assess levels of pro-inflammatory/Th1-type cytokines, IL-4 to assess levels of anti-inflammatory/ Th2-type cytokines, and IL-10 to assess levels of regulatory cytokines. In all cases, we found no significant differences between splenocytes isolated from $S c n 2 b^{+/+}$and $S c n 2 b^{-1-}$ mice.

These data indicate that the $S c n 2 b$ null mutation does not result in impairment of the release of inflammatory mediators in response to antigen.

$\mathrm{T}$ cells are critical mediators of the inflammatory process during EAE pathogenesis. EAE is considered to be a T cell-mediated autoimmune disease model (Kuchroo et al., 2002) and there is some evidence suggesting a role for $\mathrm{Na}^{+}$channels in T cells (Khan and Poisson, 1999; Lai et al., 2000). Abnormal activation of T cells is thus another possible explanation for the milder symptoms of EAE observed in the null mice. We evaluated the ability of T cells from $S c n 2 b^{+/+}$and $\operatorname{Scn} 2 b^{-/-}$mice to respond to the presence of the $\mathrm{MOG}_{35-55}$ peptide in vitro during EAE induction (Fig. 4). We obtained splenocytes from naïve and EAE-induced $S c n 2 b^{+/+}$and $S c n 2 b^{-1-}$ mice at 13 dpi and cultured them with increasing concentrations of $\mathrm{MOG}_{35-55}$ peptide. After $72 \mathrm{~h}$ in culture, proliferation was quantified by $\left[{ }^{3} \mathrm{H}\right]$-thymidine incorporation over a 24-hour period. As expected, T cells from naïve animals of either genotype that had not been previously exposed to the peptide did not display any significant proliferative response. In contrast, cells from EAE animals (both $S c n 2 b^{+/+}$and $S c n 2 b^{-/}$) exhibited a robust proliferative response at all concentrations of peptide. The magnitudes of these responses were similar for wildtype and null cells. Thus, $S c n 2 b$ deletion does not compromise the ability of T cells to proliferate in response to antigen and does not result in defects in antigen presentation or cytokine production that would influence the induction of MOG-specific T cell recall responses in vitro.

Another critical component of the immune response during EAE is the successful invasion of immune effector cells into the CNS. We labeled cross sections of spinal cord to visualize the infiltration of cells into the white matter during EAE (Fig. 5). Microglia are present in the CNS and can function as macrophages in brain. During EAE, activation of microglia occurs in 
response to injury and/or inflammation and contributes to disease pathogenesis. $\mathrm{Na}^{+}$channels have been shown to contribute to microglial activation in MS and EAE and phenytoin reduces spinal cord infiltrates in mice with EAE by 75\% (Craner et al., 2005), thus their diminished activation in $\mathrm{Scn} 2 b^{-1-}$ mice is a possible explanation for the attenuated symptoms of EAE. The OX-42 antibody recognizes a shared CD11b/CD11c epitope, the CR3 (C3bi) complement receptor and thereby labels microglia, macrophages, monocytes and granulocytes. Cells labeled in the CNS are predominantly microglia (Robinson et al., 1986). In naïve tissue, OX-42 labeling was undetectable in both $S c n 2 b^{+/+}$(Fig. 5A) and $S c n 2 b^{-/-}$(Fig. 5B) spinal cord. During EAE, OX-42 positive cells invaded the white matter in both wildtype (Fig. 5C) and null (Fig. 5D) tissue. Higher magnification views of individual cells (inset, Fig. 5C and 5D) show OX-42-positive cells with a characteristic activated morphology, having a rounded cell body and few or no processes.

$\mathrm{T}$ cells are important mediators during EAE; we have already shown that $\mathrm{T}$ cell proliferation in vitro in response to the $\mathrm{MOG}_{35-55}$ peptide is similar in cells isolated from $S c n 2 b^{+/+}$and $S c n 2 b^{-1-}$ animals (Fig. 4). Anti-CD3 antibody recognizes the T cell receptor-associated CD3 molecular complex and serves as a marker for T cells (Miescher et al., 1989). Using anti-CD3, we show that activated $\mathrm{T}$ cells are not detectable in naïve white matter isolated from either $S c n 2 b^{+/+}$(Fig. 5E) or Scn $2 b^{-/-}$(Fig. 5F) mice. During EAE, activated T cells infiltrate into the spinal cord in both genotypes with similar patterns (Fig. 5G, 5H; higher magnification views of CD3-positive cells, inset, Fig. 5G and 5H).

Coincident with the first appearance of inflammation and clinical deficits in mice with MOGEAE, glial fibrillary acidic protein (GFAP)-positive adult radial glia in spinal cord white matter undergo mitosis and phenotypic transformation to hypertrophic, stellate astroglia (Bannerman et al., 2007; Holley et al., 2003; Lee et al., 1990; Tani et al., 1996). These reactive astrocytes accumulate within and at the margins of EAE/MS lesions and function as antigen presenting cells, as well as contribute to the synthesis of pro-inflammatory cytokines (Bannerman et al., 2007; Holley et al., 2003; Lee et al., 1990; Tani et al., 1996). Anti-GFAP staining in $\operatorname{Scn} 2 b^{+/+}$and $\operatorname{Scn} 2 b^{-1-}$ spinal cord is similar under control conditions and in EAE. GFAPpositive cells in $S c n 2 b^{+/+}$(Fig. 5I) and $\operatorname{Scn} 2 b^{-/-}$(Fig. 5J) control mice are elongated with radially oriented processes. In contrast, GFAP-positive cells in $S c n 2 b^{+/+}$(Fig. 5K) and $\operatorname{Scn} 2 b^{-/-}$(Fig. 5L) mice in EAE display similar patterns, appearing to have lost their radial orientation and taken on an enlarged, stellate morphology.

Taken together, these results demonstrate that immune cell infiltration into the CNS during EAE occurs normally in $S \mathrm{Cn} 2 b^{-/-}$mice, and that there are no significant alterations under control conditions. Loss of $S c n 2 b$ does not measurably compromise the ability of the immune system to mount an appropriate inflammatory response to the presence of the $\mathrm{MOG}_{35-55}$ peptide. It is interesting that $S \mathrm{cn} 2 \mathrm{~b}^{-/-}$mice exhibit a lower percentage of demyelinated or thinly myelinated axons in optic nerve under conditions of EAE compared to wildtype mice, in spite of a normal immune response to the $\mathrm{MOG}_{35-55}$ peptide. $S c n 2 b$ is expressed in oligodendrocyte precursor cells (OPCs) as well as in neurons (Cahoy et al., 2008). Thus, similar to other cell adhesion molecules expressed by OPCs or axons (Gallo and Armstrong, 2008), $\beta 2$ may participate in inhibition of remyelination. This will be the focus of future investigations.

\section{$\mathrm{Na}^{+}$channel expression levels are altered in EAE}

Previous studies have reported changes in $\mathrm{Na}^{+}$channel expression in EAE and MS; however, these results were based on immunofluorescence rather than on biochemical methodologies that measure protein levels and thus may have reflected channel redistribution rather than upregulation (Craner et al., 2004a; Craner et al., 2004b). To address this issue, we performed a series of experiments to investigate changes in protein levels of $\mathrm{Na}^{+}$channel $\alpha$ and $\beta$ subunits in brain and spinal cord under control conditions and in EAE. Fig. 6, upper panel, shows 
changes in $\mathrm{Na}_{\mathrm{v}} 1.1, \mathrm{Na}_{\mathrm{v}} 1.2$, and $\mathrm{Na}_{\mathrm{v}} 1.6$ expression in $S c n 2 b^{+/+}$and $S c n 2 b^{-/-}$whole brain homogenates under control conditions and under conditions of EAE. Western blots were then stripped and reprobed with anti- $\alpha$-tubulin as a loading control. Our results show that $\mathrm{Na}_{\mathrm{v}} 1.6$ expression is increased in EAE in $S c n 2 b^{+/+}$brains and that this up-regulation is attenuated in $S c n 2 b^{-1-}$ brains (Fig. 6C). In contrast to predictions from previous immunofluorescent studies, we did not observe increases in overall $\mathrm{Na}_{\mathrm{v}} 1.2$ expression in brain in EAE in either genotype (Fig. 6B). We observed that $\mathrm{Na}_{\mathrm{v}} 1.1$ is increased in EAE in $S c n 2 b^{-/-}$null brain but is unaffected in $S c n 2 b^{+/+}$brain (Fig. 6A). This change in $\mathrm{Na}_{\mathrm{v}} 1.1$ expression in EAE has not been reported previously. In Fig. 6, lower panel, we show that $\beta$ subunit expression in whole brain is not altered in either genotype under control conditions or in EAE (Fig. 6D-G). Overall, we did not observe significant changes in any of the $\beta$ subunits in brain, with the exception of the absence of $\beta 2$ in the $\operatorname{Scn} 2 b^{-/-}$animals.

We next performed Western blot experiments using spinal cord homogenates to determine whether comparable changes in $\mathrm{Na}^{+}$channel expression occurred in EAE as shown above (Fig. 7). In contrast to our results in brain, but in agreement with previous reports (Craner et al., 2004a; Craner et al., 2004b), we observed increased $\mathrm{Na}_{\mathrm{v}} 1.2$ expression in $\mathrm{Scn} 2 \mathrm{~b}^{+/+}$spinal cord in EAE (Fig. 7B). Levels of $\mathrm{Na}_{\mathrm{v}} 1.2$ expression in $S c n 2 b^{-1-}$ spinal cord did not increase in demyelinating disease, consistent with our hypothesis that the absence of $\beta 2$ attenuates $\mathrm{Na}^{+}$ channel up-regulation in EAE. Similarly, we observed increased $\mathrm{Na}_{\mathrm{v}} 1.6$ expression under EAE conditions for $\operatorname{Scn} 2 b^{+/+}$but not for $S c n 2 b^{-/-}$spinal cord, again consistent with our hypothesis that $\beta 2$ contributes to this up-regulation in neurons (Fig. 7C). In contrast to the changes in $\mathrm{Na}_{\mathrm{v}} 1.1$ expression observed in brain, we observed comparable levels of this channel protein in spinal cord when comparing control and EAE conditions for each genotype.

\section{Axonal $\mathrm{Na}^{+}$channel localization is altered similarly in EAE in Scn2b+/+ and Scn2b-/- mice}

Diffuse $\mathrm{Na}_{\mathrm{v}} 1.2$ and $\mathrm{Na}_{\mathrm{v}} 1.6$ localization along demyelinated axons during EAE has been reported previously (Craner et al., 2004a; Craner et al., 2004b). We performed immunofluorescence confocal microscopy using longitudinal frozen sections of optic nerve (Fig. 8) and spinal cord (Fig. 9) from EAE and control animals to determine whether the Scn $2 b$ null mutation altered this localization pattern. In all panels of Fig. 8 and Fig. 9, antiCaspr antibody was used to mark the paranodal regions. In Fig. 8, panels A, E, and I, we show that $\mathrm{Na}_{\mathrm{v}} 1.1$ and $\mathrm{Na}_{\mathrm{v}} 1.2$ are absent from optic nerve nodes of Ranvier in adult wildtype animals under control conditions. As expected (Boiko et al., 2001; Caldwell et al., 2000; Kaplan et al., 2001), $\mathrm{Na}_{\mathrm{v}} 1.6$ is the predominant $\mathrm{Na}^{+}$channel clustered at the nodal gap. This expression pattern is not altered by the $S c n 2 b$ null mutation under control conditions (panels B, F, and J), as previously demonstrated (Chen et al., 2002). In contrast to a previous report using Biozzi mice (Craner et al., 2003), we observed the appearance of $\mathrm{Na}_{\mathrm{v}} 1.1$ at nodes in both genotypes under conditions of EAE (panels $\mathrm{C}$ and $\mathrm{D}$ ). In agreement with previous reports (Craner et al., 2004a; Craner et al., 2004b), we observed $\mathrm{Na}_{\mathrm{v}} 1.2$ and $\mathrm{Na}_{\mathrm{v}} 1.6$ immunolocalization at nodes as well as along demyelinated regions of wildtype optic nerve axons and this localization pattern was similar for $\operatorname{Scn} 2 b^{-/-}$mice (panels G, H, K, and L). Thus, while the levels of $\mathrm{Na}_{\mathrm{v}} 1.1$ and $\mathrm{Na}_{\mathrm{v}} 1.6$ protein expression are altered in $S c n 2 b$ null brain compared to wildtype under conditions of EAE, we did not observe differences in the localization patterns of these $\mathrm{Na}^{+}$ channels between genotypes in optic nerve under control or EAE conditions.

Fig. 9 demonstrates immunolocalization of $\mathrm{Na}_{\mathrm{v}} 1.1, \mathrm{Na}_{\mathrm{v}} 1.2$, and $\mathrm{Na}_{\mathrm{v}} 1.6$ in $S c n 2 b$ null and wildtype spinal cord under control conditions and in EAE. In both genotypes, under control conditions, we observed nodal clustering of predominantly $\mathrm{Na}_{\mathrm{v}} 1.1$ (panels $\mathrm{A}$ and $\mathrm{B}$ ) and $\mathrm{Na}_{\mathrm{v}} 1.6$ (panels I and $\mathrm{J}$ ), with $\mathrm{Na}_{\mathrm{v}} 1.2$ observed in a sub-population of nodes (panels $\mathrm{E}$ and $\mathrm{F}$ ). We observed $\mathrm{Na}_{\mathrm{v}} 1.1$ (panel C), $\mathrm{Na}_{\mathrm{v}} 1.2$ (panel G), and $\mathrm{Na}_{\mathrm{v}} 1.6$ (panel K) immunolocalization at nodes as well as along demyelinated regions in $S c n 2 b^{+/+}$spinal cord in EAE. A similar 
pattern was observed for $S c n 2 b^{-/-}$spinal cord in EAE (panels D, H, and L, respectively). Thus, as observed for optic nerve, the $S c n 2 b$ null mutation does not alter the pattern of $\mathrm{Na}^{+}$channel localization under control or EAE conditions. Taken together, our results suggest that the absence of $\beta 2$ alters $\mathrm{Na}^{+}$channel protein expression levels but does not affect channel localization in optic nerve or spinal cord axons under control conditions or in EAE.

\section{DISCUSSION}

$\beta 2$ subunits are critical modulators of neuronal $\mathrm{Na}^{+}$channel cell surface expression and thus, of excitability. Insertion of newly synthesized $\mathrm{Na}^{+}$channels into the plasma membrane in primary neurons is concomitant with $\alpha-\beta 2$ association (Schmidt et al., 1985; Schmidt and Catterall, 1986). Scn $2 b$ null neurons show a $\sim 50 \%$ reduction in the level of functional $\mathrm{Na}^{+}$ channels (Chen et al., 2002; Lopez-Santiago et al., 2006). In Scn2b null optic nerve, the integral of the compound action potential is reduced and the threshold for action potential generation is increased, consistent with a reduction in the level of functional cell surface $\mathrm{Na}^{+}$channels at nodes of Ranvier (Chen et al., 2002). The present study demonstrates that deletion of $S c n 2 b$ is neuroprotective in EAE in vivo. These results are consistent with the idea that axonal sparing in $S c n 2 b^{-1-}$ mice is a result of attenuated $\mathrm{Na}_{\mathrm{v}} 1.6$ upregulation in response to demyelination. In addition, these results are consistent with the possibility that, in the absence of $S c n 2 b$, there is a reduction in persistent $\mathrm{Na}^{+}$current produced by other $\mathrm{Na}^{+}$channel gene products within the lesions. Previous studies in a heterologous system have shown that the combination of $\beta 2$ $+\beta 3$ increases the level of persistent $\mathrm{Na}^{+}$current mediated by $\mathrm{Na}_{\mathrm{v}} 1.2$ expressed in tsA-201 cells while the combination of $\beta 1+\beta 2$ has no effect on persistent current (Qu et al., 2001). Thus, the specific combination of $\mathrm{Na}^{+}$channel $\alpha$ and $\beta$ subunits is likely critical to determining the level of persistent $\mathrm{Na}^{+}$current in demyelinated axons.

Similar to the mechanism put forth by Waxman and colleagues (Waxman, 2006), we propose that in $S c n 2 b$ wildtype and null mice $\mathrm{Na}_{\mathrm{v}} 1.2$ is diffusely expressed along demyelinated axons in EAE where it supports recovery from conduction block. $\mathrm{Na}_{\mathrm{v}} 1.6$ becomes up-regulated along some demyelinated axons in wildtype mice in EAE and contributes to axonal damage via mediation of persistent $\mathrm{Na}^{+}$current followed by accumulation of intra-axonal $\mathrm{Na}^{+}$, activation of reverse $\mathrm{Na}^{+}-\mathrm{Ca}^{2+}$ exchange, and accumulation of intra-axonal $\mathrm{Ca}^{2+}$. We propose that $S c n 2 b^{-1-}$ mice are protected from axonal damage during EAE due to attenuation of $\mathrm{Na}_{\mathrm{v}} 1.6$ upregulation along demyelinated axons, thus reducing the harmful effects of the predicted persistent $\mathrm{Na}^{+}$current. In addition, the absence of $\beta 2$ may attenuate the level of persistent $\mathrm{Na}^{+}$current mediated by $\mathrm{Na}^{+}$channels in demyelinated lesions. The observed appearance of $\mathrm{Na}_{\mathrm{v}} 1.1$ at optic nerve nodes of Ranvier in EAE in both genotypes, as well as increased expression of $\mathrm{Na}_{\mathrm{v}} 1.1$ protein in $S c n 2 b^{-/-}$brain during EAE, compared to $S c n 2 b^{+/+}$, provide an intriguing avenue of investigation for future work, as the involvement of $\mathrm{Na}_{\mathrm{v}} 1.1$ in demyelination has not been investigated. The level of persistent current generated by $\mathrm{Na}_{\mathrm{v}} 1.1$ in native optic nerve axons is not known (Lossin et al., 2003; Spampanato et al., 2004; Vanoye et al., 2006), thus we are unable to predict whether an increase in $\mathrm{Na}_{\mathrm{v}} 1.1$ expression during demyelination would lead to axonal degeneration similar to that proposed for $\mathrm{Na}_{\mathrm{v}} 1.6$. The reduction in axonal loss observed in $\operatorname{Scn} 2 b^{-/-}$mice compared to $S c n 2 b^{+/+}$however, suggests that $\mathrm{Na}_{\mathrm{v}} 1.1$-mediated $\mathrm{Na}^{+}$current in the absence of $\beta 2$ does not activate injury cascades, and may instead promote recovery from conduction block, as predicted for $\mathrm{Na}_{\mathrm{v}} 1.2$. Thus, the role of $\mathrm{Na}^{+}$channels in demyelinating disease is complex, with relative expression levels of different channel genes predicted to provide critical modulation of the eventual course of the disease and extent of pathology. Importantly, our results demonstrate that $\operatorname{Scn} 2 \mathrm{~b}^{-/-}$mice have normal inflammatory and immune responses in EAE, supporting our hypothesis that the mechanism of neuroprotection in these mice is due to changes in the expression levels of axonal $\mathrm{Na}^{+}$channels rather than to immunomodulation. Intriguingly, it was shown previously that $S c n 2 b$ mRNA levels are down-regulated at advanced stages of monophasic EAE in rats (Nicot 
et al., 2003). This may represent a compensatory mechanism in neurons to attenuate the damaging effects of $\mathrm{Na}_{\mathrm{v}} 1.6$ up-regulation in demyelinating disease and is consistent with the present results in $S c n 2 b$ null mice.

Our results suggest a molecular mechanism for the observed pharmacological effects of $\mathrm{Na}^{+}$ channel blocking agents in MS/EAE and may open a novel avenue for therapeutic intervention. We propose that administration of drugs targeting $\mathrm{Na}^{+}$channels effectively results in a similar situation in neurons as loss of $\beta 2-$ a significant reduction in the level of functional $\mathrm{Na}^{+}$ channels. Deletion of $\mathrm{Na}^{+}$channel $\alpha$ subunits in mice is lethal (reviewed in (Meadows and Isom, 2005)). Administration of $\mathrm{Na}^{+}$channel pharmacological agents (e.g. anti-convulsants, anti-arrhythmics, and local anesthetics), while effective in MS, can also result in serious systemic side effects. For example, recent studies have shown that withdrawal of phenytoin can exacerbate symptoms and result in lethality in the EAE model (Black et al., 2007). Our approach, in contrast, is novel and opens the possibility that through targeting $\beta 2$, the level of cell surface $\mathrm{Na}^{+}$channel expression can be incrementally and perhaps specifically modulated, so that in the future safer and more effective therapies for protection against axonal loss following neuronal injury and/or demyelination may be realized.

\section{EXPERIMENTAL METHODS}

\section{Mice}

$\operatorname{Scn} 2 b^{+/+}$and $\operatorname{Scn} 2 b^{-/-}$mice were generated in our laboratory on the C57BL/6 genetic background (Chen et al., 2002), and have been established as congenic strains through repeated backcrossing to C57BL/6 mice for over 15 generations. All mice used in this study were female $S c n 2 b^{+/+}$or $S c n 2 b^{-/-}$mice bred from congenic $S c n 2 b^{+/-}$littermates, between the ages of 12 and 24 weeks of age. All animal procedures were approved by the University of Michigan Committee on the Use and Care of Animals and mice were housed in the University of Michigan Unit for Laboratory Animal Medicine.

\section{Induction of EAE}

$\mathrm{MOG}_{35-55}$ peptide was synthesized and purified by the University of Michigan Protein Structure Facility, Ann Arbor, MI or by Auspep, Parkville, Australia. Peptides were tested between both facilities to ensure that disease progression was identical; individual lots from each facility were also tested upon receipt. $150 \mu \mathrm{g}$ of purified $\mathrm{MOG}_{35-55}$ peptide were emulsified in sterile PBS and complete Freund's adjuvant (CFA; Difco, Franklin Lakes, NJ), and supplemented with $4 \mathrm{mg} / \mathrm{ml}$

\section{Mycobacterium tuberculosis (Difco)}

$100 \mu 1$ of emulsion, or emulsion lacking peptide (as a control), were injected subcutaneously into each hind flank of the animal. All animals (peptide and control groups) were immediately injected intravenously with $350 \mathrm{ng}$ of inactivated pertussis toxin (List Biological Laboratories, Campbell, CA) in sterile PBS and again after 48 hours. Animals were monitored daily for the development of clinical symptoms following induction using a five-point clinical scale as follows: 0: no visible impairment, 1: limp tail, 2: limp tail with hind limb weakness, 3: hind limb paralysis, 4: ascending paralysis with hind limb paralysis, 5: moribund or death. Animals in between two stages were given half scores. Animals reaching stage 5 were assigned a score of 5 for the remainder of the experimental time course. Animals experiencing paralysis were given water ad libitum, moist chow was placed on the cage floor twice daily, and animals were hand-fed when necessary. 


\section{Transmission Electron Microscopy}

$\operatorname{Scn} 2 b^{+/+}$and Scn $2 b^{-/-}$mice (MOG peptide and control groups), at time points post-injection indicated in the figure legends, were anesthetized and perfused intracardially with $0.1 \mathrm{M}$ Sorenson's buffer ( $\mathrm{pH}$ 7.4) followed by $2.5 \%$ glutaraldehyde in Sorenson's buffer. Nerves were carefully dissected and placed in fresh fixative for a minimum of $2 \mathrm{~h}$, rinsed, and post-fixed in $1 \%$ osmium tetroxide. Samples were washed in several changes of buffer, dehydrated with graded alcohols and embedded in Spurr's epoxy resin. Semi-thin sections were stained with $1 \%$ toluidine blue for morphological examination and to establish orientation. Ultrathin (70 $\mathrm{nm}$ ) transverse sections were then stained in uranyl acetate/lead citrate. For analysis, one ultrathin section from each of three mice under control or EAE conditions was examined using a Phillips CM-100 TEM located in the Microscopy and Image Analysis Laboratory (MIAL), University of Michigan. A minimum of fifty non-overlapping fields of view $\left(160.4 \mu^{2}\right.$ per field of view) from each section were obtained at 7900x magnification. From each image, total numbers of myelinated axons were counted manually (including both intact and degenerating axons). In the same images, the number of degenerating axons was counted. The percentage of degenerating axons was calculated per field of view and values for all fields of view in each group of mice were averaged. A myelinated axon was defined as an axon wrapped by two or more layers of myelin. A degenerating axon was defined as a collapsed or delaminated myelinated axon containing membranous debris. Images were digitally recorded using a Kodak 1.6 Megaplus high-resolution digital camera system. All values are reported as mean \pm SEM. This assessment was first performed by the investigator who prepared the samples and then was repeated by another investigator who was blind to genotype and experimental condition. Both investigators calculated similar values.

\section{Splenocyte Culture}

Spleens were removed from control and peptide groups of $\operatorname{Scn} 2 b^{+/+}$and $S c n 2 b^{-/-}$mice at $12-$ 14 dpi. The spleens were mechanically separated, triturated, and washed to obtain a single-cell suspension of splenocytes. Red blood cells were lysed and splenocytes washed in HBSS. Cells were counted and cultured in RPMI supplemented with 5\% fetal bovine serum (Invitrogen), $1 \%$ penicillin/streptomycin (Invitrogen), $200 \mathrm{mM} \mathrm{L}$-glutamine (Invitrogen), $100 \mathrm{mM}$ sodium pyruvate (Invitrogen), $10 \mathrm{mM}$ non-essential amino acids (Invitrogen) and $50 \mu \mathrm{M} \beta$ mercaptoethanol (Sigma-Aldrich). $\mathrm{MOG}_{35-55}$ peptide was added to all culture wells at a concentration of $20 \mu \mathrm{g} / \mathrm{ml}$, with the exception of cultures used for T cell proliferation assays, which were cultured with varying concentrations of peptide as indicated in the figure.

\section{Fluorescence-activated cell sorting}

For surface staining, spleen cells were washed and resuspended at a concentration of $10^{7}$ cells/ $\mathrm{ml}$ in FA Buffer (Difco) $+0.1 \% \mathrm{NaN}_{3}$. Fc receptors were blocked by the addition of antiCD16/32 (Fc block; BD Pharmingen). After Fc receptor blocking, $10^{6}$ cells were stained in a final volume of $120 \mu \mathrm{l}$ in $12 \times 75$ polystyrene tubes for $30 \mathrm{~min}$ at $4^{\circ} \mathrm{C}$. Leukocytes were stained with the following monoclonal antibodies, according to the manufacturer's instructions: CD4 (RM4-5), CD8a (53-6.7), CD3 (17A2), CD19 (ID3), CD11c (HL3) (all BD Pharmingen). Cells were washed twice with FA buffer, resuspended in $100 \mu \mathrm{l}$ buffer, and $200 \mu \mathrm{l}$ of $4 \%$ formalin was added to fix the cells. Cells were gated for live cells by forward scatter (FSC) and side scatter (SSC) before analysis. A minimum of 20,000 events were acquired on a FACSCalibur flow cytometer (BD Pharmingen) using CellQuest software (BD Pharmingen).

\section{T cell proliferation/ELISA}

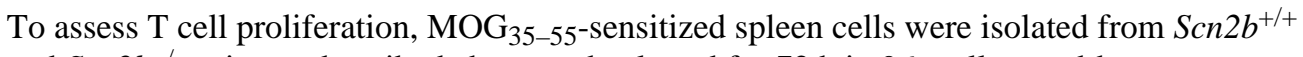
and $\operatorname{Scn} 2 b^{-1-}$ mice as described above and cultured for $72 \mathrm{~h}$ in 96-well, round-bottom microculture plates at a concentration of $5 \times 10^{6} \mathrm{cells} / \mathrm{ml}$ in $0.2 \mathrm{ml}$ of RPMI-complete medium 
in the presence or absence of $5-80 \mu \mathrm{g} / \mathrm{ml} \mathrm{MOG}_{35-55}$ peptide. For proliferation, $\left[{ }^{3} \mathrm{H}\right]$-thymidine $(1 \mu \mathrm{Ci} /$ well, MP Biomedicals, Irvine, CA) was added at $72 \mathrm{~h}$, and mean incorporation into DNA was measured at $96 \mathrm{~h}$ by liquid scintillation counting. To measure the levels of Th1 and Th2 cytokines, $\mathrm{MOG}_{35-55}$-immunized spleen cells $\left(5 \times 10^{6} / \mathrm{ml}\right)$ were cultured in RPMIcomplete medium in 6-well plates in the presence or absence of $20 \mu \mathrm{g} / \mathrm{ml} \mathrm{MOG}_{35-55}$ peptide. After $72 \mathrm{~h}$, cells were recultured in the presence of $\mathrm{MOG}_{35-55}$ peptide in 24-well plates at $1 \times$ $10^{6} / \mathrm{ml}$. After $24 \mathrm{~h}$, the culture supernatants were collected and assessed for cytokine production. The levels of Th1 (IFN- $\gamma$ ), Th2 (IL-4) and Th2/Treg (IL-10) cytokines in culture supernatants were measured by the ELISA OPTEIA (IL-4 and IL-10; BD Pharmingen) or DuoSet (IFN $\gamma ;$ R\&D Systems, Minneapolis, MN) system according to the manufacturer's instructions.

\section{Immunofluorescence Microscopy}

Spinal cords or optic nerves were dissected from $S c n 2 b^{+/+}$and $S c n 2 b^{-1-}$ mice (MOG peptide and control) at the time post-injection indicated in the figure legends. $10 \mu \mathrm{m}$ cryosections were generated. Sections were fixed with $4 \%$ paraformaldehyde, washed 3 times in $0.05 \mathrm{M}$ phosphate buffer (PB), and blocked for a minimum of $1 \mathrm{~h}$ in PBTGS (0.1M PB, 0.3\% Triton $\mathrm{X}-100,10 \%$ normal goat serum). Sections were incubated overnight in primary antibody diluted in PBTGS, followed by incubation in goat anti-mouse, anti-rabbit or anti-rat secondary antibody as appropriate, coupled to either Alexa 488 (green) or Alexa 594 (red) (Molecular Probes, Carlsbad, CA) and diluted in PBTGS. Sections were washed three times with $0.1 \mathrm{M}$ PB after each antibody step. Sections were air-dried and coverslipped using GelMount antifade mounting medium (Biomeda, Foster City, CA). Digital images were collected using an Olympus FluoView 500 confocal microscope with FluoView software located in the Department of Pharmacology, University of Michigan, or an Olympus BX51 fluorescent microscope located in the University of Michigan Microscopy and Image Analysis Laboratory.

\section{Western blot}

$\operatorname{Scn} 2 b^{+/+}$and $\operatorname{Scn} 2 b^{-/-}$mice were sacrificed and brains and spinal cords were immediately removed and stored in ice-cold homogenization buffer. Membranes were prepared as described previously (Isom et al., 1995). For splenocyte preparations, cells were isolated as described above and lysed with RIPA buffer. 'Complete' protease inhibitor tablets (Roche Diagnostics, Indianapolis, IN) were included in all solutions at twice the recommended concentration to prevent $\mathrm{Na}^{+}$channel degradation. Western blot analysis was then performed as described (Malhotra et al., 2000; Malhotra et al., 2004) to detect $\mathrm{Na}^{+}$channel $\alpha$ and $\beta$ subunit polypeptides, as described in the figure legends. Briefly, samples were solubilized in SDSPAGE sample buffer containing 1\% SDS and $500 \mathrm{mM} \beta$-mercaptoethanol, heated for $5 \mathrm{~min}$ at $80^{\circ} \mathrm{C}$, and separated on 4-15\% acrylamide SDS-PAGE gradient gels for $\alpha$ subunit detection or $10 \%$ acrylamide SDS-PAGE gels for $\beta$ subunit detection. Proteins were transferred to nitrocellulose and probed with specific antibodies followed by secondary antibodies conjugated to horseradish peroxidase and visualized using the West Dura or West Femto enhanced chemiluminescence detection system (Pierce, Rockford, IL). Blots which were reincubated with a second primary antibody against $\alpha$-tubulin (as a loading control) were first stripped with ReBlot Plus Antibody Stripping Solution (Chemicon, Temecula, CA) according to manufacturer's instructions. For quantification of Western blots, densitometric analysis of bands was performed using NIH ImageJ software. Band density was normalized to $\alpha$-tubulin signal for comparison.

\section{Antibodies}

Primary antibodies for Western blotting and immunocytochemistry were used as follows: antiCD3 (dilution 1:250, BD Pharmingen, San Jose, CA), OX-42 (1:100, BD Pharmingen), anti- 
GFAP (1:500, Molecular Probes, Carlsbad, CA), anti-Na 1.1 (1:100-1:250, NeuroMab, Davis, CA), anti-Na 1.2 (1:100-1:250, NeuroMab), anti-Na 1.6 (either 1:200 (polyclonal, Western blotting, Sigma-Aldrich) or 1:200 (monoclonal, immunofluorescence, NeuroMab)), anti-Caspr (either 1:1500 (polyclonal, Dr. Elior Peles) or 1:500 (monoclonal, NeuroMab)), anti- $\beta 1$ (antiscn1ba1 (Fein et al., 2007)), anti- $\beta 2$ ec (a resynthesis of anti- $\beta 2$ ec antibody previously characterized in (Chen et al., 2002)), anti- $\beta 3$ (Chen et al., 2004), anti- $\beta 4$ (a polyclonal antibody to $\beta 4$ was generated against the peptide sequence KKLITFILKKTREKKKECLV used in (Grieco et al., 2005)), and anti- $\alpha$-tubulin (1:5000, Cedarlane Laboratories, Hornby, ON).

\section{Statistical Analysis}

Data were calculated as mean $+/-$ SEM, compared using the Student's t-test, and plotted using GraphPad Prism statistical software. Significant differences were defined as $\mathrm{p}<0.05$.

\section{Acknowledgements}

We thank Travis Dickendesher and Audrey Speelman for expert mouse husbandry, and Diana Schorry and Leah Zhou for technical assistance. We received invaluable assistance with microscopy training, sample preparation and advice from Sasha Meshinchi, Dorothy Sorenson and Chris Edwards at the University of Michigan Microscopy and Image Analysis Laboratory. The rabbit anti-Caspr antibody was a generous gift from Dr. Elior Peles, Weizmann Institute of Science, Rehovot, Israel.

Supported by National Multiple Sclerosis Society Research Grants RG2882 and RG3771A4/3 and Pilot Grant PP1300 to LLI, by a grant from the Wilson Medical Research Foundation to LLI, by the University of Michigan Training Program in Cellular and Molecular Biology to HOM (NIH GM007315-31), and by the University of Michigan Center for Organogenesis Training Grant to HOM (NIH 5-T32-HD007505). This work utilized the Protein Core of the Michigan Diabetes Research and Training Center, funded by NIH5P60 DK20572 from the National Institute of Diabetes \& Digestive \& Kidney Diseases.

\section{References}

Bannerman P, Hahn A, Soulika A, Gallo V, Pleasure D. Astrogliosis in EAE spinal cord: derivation from radial glia, and relationships to oligodendroglia. Glia 2007;55:57-64. [PubMed: 17009237]

Bechtold DA, Smith KJ. Sodium-mediated axonal degeneration in inflammatory demyelinating disease. J Neurol Sci 2005;233:27-35. [PubMed: 15894334]

Bechtold DA, Yue X, Evans RM, Davies M, Gregson NA, Smith KJ. Axonal protection in experimental autoimmune neuritis by the sodium channel blocking agent flecainide. Brain 2005;128:18-28. [PubMed: 15509620]

Besancon E, Guo S, Lok J, Tymianski M, Lo EH. Beyond NMDA and AMPA glutamate receptors: emerging mechanisms for ionic imbalance and cell death in stroke. Trends in pharmacological sciences 2008;29:268-275. [PubMed: 18384889]

Bielefeldt K, Whiteis CA, Chapleau MW, Abboud FM. Nitric oxide enhances slow inactivation of voltage-dependent sodium currents in rat nodose neurons. Neuroscience letters 1999;271:159-162. [PubMed: 10507693]

Bjartmar C, Wujek JR, Trapp BD. Axonal loss in the pathology of MS: consequences for understanding the progressive phase of the disease. J Neurol Sci 2003;206:165-171. [PubMed: 12559505]

Black JA, Liu S, Carrithers M, Carrithers LM, Waxman SG. Exacerbation of experimental autoimmune encephalomyelitis after withdrawal of phenytoin and carbamazepine. Ann Neurol 2007;62:21-33. [PubMed: 17654737]

Boiko T, Rasband M, Levinson S, Caldwell J, Mandel G, Trimmer J, Matthews G. Compact myelin dictates the differential targeting of two sodium channel isoforms in the same axon. Neuron 2001;30:91-104. [PubMed: 11343647]

Burbidge SA, Dale TJ, Powell AJ, Whitaker WR, Xie XM, Romanos MA, Clare JJ. Molecular cloning, distribution and functional analysis of the NA(V)1.6. Voltage-gated sodium channel from human brain. Brain Res Mol Brain Res 2002;103:80-90. [PubMed: 12106694] 
Cahoy JD, Emery B, Kaushal A, Foo LC, Zamanian JL, Christopherson KS, Xing Y, Lubischer JL, Krieg PA, Krupenko SA, Thompson WJ, Barres BA. A transcriptome database for astrocytes, neurons, and oligodendrocytes: a new resource for understanding brain development and function. J Neurosci 2008;28:264-278. [PubMed: 18171944]

Caldwell JH, Schaller KL, Lasher RS, Peles E, Levinson SR. Sodium channel Na(v)1.6 is localized at nodes of ranvier, dendrites, and synapses. Proc Natl Acad Sci U S A 2000;97:5616-5620. [PubMed: 10779552]

Chabas D, Baranzini SE, Mitchell D, Bernard CC, Rittling SR, Denhardt DT, Sobel RA, Lock C, Karpuj M, Pedotti R, Heller R, Oksenberg JR, Steinman L. The influence of the proinflammatory cytokine, osteopontin, on autoimmune demyelinating disease. Science 2001;294:1731-1735. [PubMed: 11721059]

Chen C, Bharucha V, Chen Y, Westenbroek RE, Brown A, Malhotra JD, Jones D, Avery C, Gillespie PJ 3rd, Kazen-Gillespie KA, Kazarinova-Noyes K, Shrager P, Saunders TL, Macdonald RL, Ransom BR, Scheuer T, Catterall WA, Isom LL. Reduced sodium channel density, altered voltage dependence of inactivation, and increased susceptibility to seizures in mice lacking sodium channel beta 2subunits. Proc Natl Acad Sci U S A 2002;99:17072-17077. [PubMed: 12481039]

Chen C, Westenbroek RE, Xu X, Edwards CA, Sorenson DR, Chen Y, McEwen DP, O'Malley HA, Bharucha V, Meadows LS, Knudsen GA, Vilaythong A, Noebels JL, Saunders TL, Scheuer T, Shrager P, Catterall WA, Isom LL. Mice lacking sodium channel beta1 subunits display defects in neuronal excitability, sodium channel expression, and nodal architecture. J Neurosci 2004;24:40304042. [PubMed: 15102918]

Coleman M. Axon degeneration mechanisms: commonality amid diversity. Nat Rev Neurosci 2005;6:889-898. [PubMed: 16224497]

Craner MJ, Damarjian TG, Liu S, Hains BC, Lo AC, Black JA, Newcombe J, Cuzner ML, Waxman SG. Sodium channels contribute to microglia/macrophage activation and function in EAE and MS. Glia 2005;49:220-229. [PubMed: 15390090]

Craner MJ, Hains BC, Lo AC, Black JA, Waxman SG. Co-localization of sodium channel Nav1.6 and the sodium-calcium exchanger at sites of axonal injury in the spinal cord in EAE. Brain 2004a; 127:294-303. [PubMed: 14662515]

Craner MJ, Lo AC, Black JA, Waxman SG. Abnormal sodium channel distribution in optic nerve axons in a model of inflammatory demyelination. Brain 2003;126:1552-1561. [PubMed: 12805113]

Craner MJ, Newcombe J, Black JA, Hartle C, Cuzner ML, Waxman SG. Molecular changes in neurons in multiple sclerosis: altered axonal expression of Nav1.2 and Nav1.6 sodium channels and $\mathrm{Na}+\mathrm{Ca} 2$ + exchanger. Proc Natl Acad Sci U S A 2004b;101:8168-8173. [PubMed: 15148385]

Dave JR, Lin Y, Ved HS, Koenig ML, Clapp L, Hunter J, Tortella FC. RS-100642-198, a novel sodium channel blocker, provides differential neuroprotection against hypoxia/hypoglycemia, veratridine or glutamate-mediated neurotoxicity in primary cultures of rat cerebellar neurons. Neurotox Res 2001;3:381-395. [PubMed: 14715468]

Dutta R, Trapp BD. Pathogenesis of axonal and neuronal damage in multiple sclerosis. Neurology 2007;68:S22-31. [PubMed: 17548565]discussion S43-54

England JD, Gamboni F, Levinson SR. Increased numbers of sodium channels form along demyelinated axons. Brain Res 1991;548:334-337. [PubMed: 1651145]

England JD, Gamboni F, Levinson SR, Finger TE. Changed distribution of sodium channels along demyelinated axons. Proc Natl Acad Sci USA 1990;87:6777-6780. [PubMed: 2168559]

Fein AJ, Meadows LS, Chen C, Slat EA, Isom LL. Cloning and expression of a zebrafish SCN1B ortholog and identification of a species-specific splice variant. BMC Genomics 2007;8:226. [PubMed: 17623064]

Fern R, Ransom BR, Stys PK, Waxman SG. Pharmacological protection of CNS white matter during anoxia: actions of phenytoin, carbamazepine and diazepam. The Journal of pharmacology and experimental therapeutics 1993;266:1549-1555. [PubMed: 8371157]

Forte M, Gold BG, Marracci G, Chaudhary P, Basso E, Johnsen D, Yu X, Fowlkes J, Bernardi P, Bourdette D. Cyclophilin D inactivation protects axons in experimental autoimmune encephalomyelitis, an animal model of multiple sclerosis. Proc Natl Acad Sci U S A 2007;104:7558-7563. [PubMed: 17463082] 
Frohman EM, Filippi M, Stuve O, Waxman SG, Corboy J, Phillips JT, Lucchinetti C, Wilken J, Karandikar N, Hemmer B, Monson N, De Keyser J, Hartung H, Steinman L, Oksenberg JR, Cree BA, Hauser S, Racke MK. Characterizing the mechanisms of progression in multiple sclerosis: evidence and new hypotheses for future directions. Arch Neurol 2005;62:1345-1356. [PubMed: 16157741]

Gallo V, Armstrong RC. Myelin repair strategies: a cellular view. Curr Opin Neurol 2008;21:278-283. [PubMed: 18451710]

Grieco TM, Malhotra JD, Chen C, Isom LL, Raman IM. Open-channel block by the cytoplasmic tail of sodium channel $\beta 4$ as a mechanism for resurgent sodium current. Neuron 2005;45:233-244. [PubMed: 15664175]

Hains BC, Saab CY, Lo AC, Waxman SG. Sodium channel blockade with phenytoin protects spinal cord axons, enhances axonal conduction, and improves functional motor recovery after contusion SCI. Experimental neurology 2004;188:365-377. [PubMed: 15246836]

Hains BC, Waxman SG. Neuroprotection by sodium channel blockade with phenytoin in an experimental model of glaucoma. Invest Ophthalmol Vis Sci 2005;46:4164-4169. [PubMed: 16249495]

Hammarstrom AK, Gage PW. Nitric oxide increases persistent sodium current in rat hippocampal neurons. J Physiol 520 Pt 1999;2:451-461.

Hemmings HC Jr. Neuroprotection by Na+ channel blockade. J Neurosurg Anesthesiol 2004;16:100101. [PubMed: 14676580]

Herzog RI, Cummins TR, Ghassemi F, Dib-Hajj SD, Waxman SG. Distinct repriming and closed-state inactivation kinetics of Nav1.6 and Nav1.7 sodium channels in mouse spinal sensory neurons. J Physiol 2003;551:741-750. [PubMed: 12843211]

Hewitt KE, Stys PK, Lesiuk HJ. The use-dependent sodium channel blocker mexiletine is neuroprotective against global ischemic injury. Brain Res 2001;898:281-287. [PubMed: 11306014]

Holley JE, Gveric D, Newcombe J, Cuzner ML, Gutowski NJ. Astrocyte characterization in the multiple sclerosis glial scar. Neuropathol Appl Neurobiol 2003;29:434-444. [PubMed: 14507335]

Isom LL, Scheuer T, Brownstein AB, Ragsdale DS, Murphy BJ, Catterall WA. Functional co-expression of the $\beta 1$ and type IIA $\alpha$ subunits of sodium channels in a mammalian cell line. J Biol Chem 1995;270:3306-3312. [PubMed: 7852416]

Kaplan MR, Cho MH, Ullian EM, Isom LL, Levinson SR, Barres BA. Differential control of clustering of the sodium channels Nav1.2 and Nav1.6 at developing CNS nodes of Ranvier. Neuron 2001;30:105-119. [PubMed: 11343648]

Kapoor R. Sodium channel blockers and neuroprotection in multiple sclerosis using lamotrigine. J Neurol Sci. 2008

Kaptanoglu E, Solaroglu I, Surucu HS, Akbiyik F, Beskonakli E. Blockade of sodium channels by phenytoin protects ultrastructure and attenuates lipid peroxidation in experimental spinal cord injury. Acta Neurochir (Wien) 2005;147:405-412. [PubMed: 15696267]

Khan NA, Poisson JP. 5-HT3 receptor-channels coupled with Na+ influx in human T cells: role in T cell activation. J Neuroimmunol 1999;99:53-60. [PubMed: 10496177]

Kuchroo VK, Anderson AC, Waldner H, Munder M, Bettelli E, Nicholson LB. T cell response in experimental autoimmune encephalomyelitis (EAE): role of self and cross-reactive antigens in shaping, tuning, and regulating the autopathogenic T cell repertoire. Annu Rev Immunol 2002;20:101-123. [PubMed: 11861599]

Kurnellas MP, Nicot A, Shull GE, Elkabes S. Plasma membrane calcium ATPase deficiency causes neuronal pathology in the spinal cord: a potential mechanism for neurodegeneration in multiple sclerosis and spinal cord injury. Faseb J 2005;19:298-300. [PubMed: 15576480]

Lai ZF, Chen YZ, Nishimura Y, Nishi K. An amiloride-sensitive and voltage-dependent Na+ channel in an HLA-DR-restricted human T cell clone. J Immunol 2000;165:83-90. [PubMed: 10861038]

Lee SC, Moore GR, Golenwsky G, Raine CS. Multiple sclerosis: a role for astroglia in active demyelination suggested by class II MHC expression and ultrastructural study. J Neuropathol Exp Neurol 1990;49:122-136. [PubMed: 2307980]

Li Z, Chapleau MW, Bates JN, Bielefeldt K, Lee HC, Abboud FM. Nitric oxide as an autocrine regulator of sodium currents in baroreceptor neurons. Neuron 1998;20:1039-1049. [PubMed: 9620707] 
Lo AC, Black JA, Waxman SG. Neuroprotection of axons with phenytoin in experimental allergic encephalomyelitis. Neuroreport 2002;13:1909-1912. [PubMed: 12395089]

Lo AC, Saab CY, Black JA, Waxman SG. Phenytoin protects spinal cord axons and preserves axonal conduction and neurological function in a model of neuroinflammation in vivo. J Neurophysiol 2003;90:3566-3571. [PubMed: 12904334]

Lopez-Santiago LF, Pertin M, Morisod X, Chen C, Hong S, Wiley J, Decosterd I, Isom LL. Sodium channel $\beta 2$ subunits regulate tetrodotoxin-sensitive sodium channels in small dorsal root ganglion neurons and modulate the response to pain. J Neurosci 2006;26:7984-7994. [PubMed: 16870743]

Lossin C, Rhodes TH, Desai RR, Vanoye CG, Wang D, Carniciu S, Devinsky O, George AL Jr. Epilepsyassociated dysfunction in the voltage-gated neuronal sodium channel SCN1A. J Neurosci 2003;23:11289-11295. [PubMed: 14672992]

Malhotra JD, Kazen-Gillespie K, Hortsch M, Isom LL. Sodium channel $\beta$ subunits mediate homophilic cell adhesion and recruit ankyrin to points of cell-cell contact. J Biol Chem 2000;275:11383-11388. [PubMed: 10753953]

Malhotra JD, Thyagarajan V, Chen C, Isom LL. Tyrosine-phosphorylated and nonphosphorylated sodium channel beta1 subunits are differentially localized in cardiac myocytes. J Biol Chem 2004;279:40748-40754. [PubMed: 15272007]

McQualter JL, Darwiche R, Ewing C, Onuki M, Kay TW, Hamilton JA, Reid HH, Bernard CC. Granulocyte macrophage colony-stimulating factor: a new putative therapeutic target in multiple sclerosis. J Exp Med 2001;194:873-882. [PubMed: 11581310]

Meadows LS, Isom LL. Sodium channels as macromolecular complexes: implications for inherited arrhythmia syndromes. Cardiovascular Research 2005;67:448-458. [PubMed: 15919069]

Miescher GC, Schreyer M, MacDonald HR. Production and characterization of a rat monoclonal antibody against the murine CD3 molecular complex. Immunology letters 1989;23:113-118. [PubMed: 2534389]

Moll C, Mourre C, Lazdunski M, Ulrich J. Increase of sodium channels in demyelinated lesions of multiple sclerosis. Brain Res 1991;556:311-316. [PubMed: 1657307]

Nicot A, Ratnakar PV, Ron Y, Chen CC, Elkabes S. Regulation of gene expression in experimental autoimmune encephalomyelitis indicates early neuronal dysfunction. Brain 2003;126:398-412. [PubMed: 12538406]

Papazisis G, Kallaras K, Kaiki-Astara A, Pourzitaki C, Tzachanis D, Dagklis T, Kouvelas D. Neuroprotection by lamotrigine in a rat model of neonatal hypoxic-ischaemic encephalopathy. The international journal of neuropsychopharmacology/official scientific journal of the Collegium Internationale Neuropsychopharmacologicum (CINP) 2008;11:321-329. [PubMed: 17897482]

Qu Y, Curtis R, Lawson D, Gilbride K, Ge P, DiStefano PS, Silos-Santiago I, Catterall WA, Scheuer T. Differential modulation of sodium channel gating and persistent sodium currents by the beta1, beta2, and beta3 subunits. Mol Cell Neurosci 2001;18:570-580. [PubMed: 11922146]

Robinson AP, White TM, Mason DW. Macrophage heterogeneity in the rat as delineated by two monoclonal antibodies MRC OX-41 and MRC OX-42, the latter recognizing complement receptor type 3. Immunology 1986;57:239-247. [PubMed: 3512425]

Rush AM, Dib-Hajj SD, Waxman SG. Electrophysiological properties of two axonal sodium channels, Nav1.2 and Nav1.6, expressed in mouse spinal sensory neurones. J Physiol 2005;564:803-815. [PubMed: 15760941]

Sareen D. Neuroprotective agents in acute ischemic stroke. J Assoc Physicians India 2002;50:250-258. [PubMed: 12038658]

Schmidt J, Rossie S, Catterall WA. A large intracellular pool of inactive Na channel alpha subunits in developing rat brain. Proc Natl Acad Sci U S A 1985;82:4847-4851. [PubMed: 2410908]

Schmidt JW, Catterall WA. Biosynthesis and processing of the alpha subunit of the voltage-sensitive sodium channel in rat brain neurons. Cell 1986;46:437-445. [PubMed: 2425982]

Schwartz G, Fehlings MG. Evaluation of the neuroprotective effects of sodium channel blockers after spinal cord injury: improved behavioral and neuroanatomical recovery with riluzole. J Neurosurg 2001;94:245-256. [PubMed: 11302627]

Smith KJ. Sodium channels and multiple sclerosis: roles in symptom production, damage and therapy. Brain pathology (Zurich, Switzerland) 2007;17:230-242. 
Smith MR, Smith RD, Plummer NW, Meisler MH, Goldin AL. Functional analysis of the mouse Scn8a sodium channel. J Neurosci 1998;18:6093-6102. [PubMed: 9698304]

Spampanato J, Kearney JA, de Haan G, McEwen DP, Escayg A, Aradi I, MacDonald BT, Levin SI, Soltesz I, Benna P, Montalenti E, Isom LL, Goldin AL, Meisler MH. A novel epilepsy mutation in the sodium channel SCN1A identifies a cytoplasmic domain for beta subunit interaction. J Neurosci 2004;24:10022-10034. [PubMed: 15525788]

Stys P, Ransom BR, Waxman SG. Compound action potential of nerve recorded by suction electrode: theoretical and experimental analysis. Brain Res 1991;546:18-32. [PubMed: 1855148]

Stys PK. General mechanisms of axonal damage and its prevention. J Neurol Sci 2005;233:3-13. [PubMed: 15899499]

Stys PK, Waxman SG, Ransom BR. Ionic mechanisms of anoxic injury in mammalian CNS white matter: Role of $\mathrm{Na}^{+}$channels and $\mathrm{Na}^{+}-\mathrm{Ca}^{2+}$ exchanger. J Neurosci 1992;12:430-439. [PubMed: 1311030]

Tani M, Glabinski AR, Tuohy VK, Stoler MH, Estes ML, Ransohoff RM. In situ hybridization analysis of glial fibrillary acidic protein mRNA reveals evidence of biphasic astrocyte activation during acute experimental autoimmune encephalomyelitis. Am J Pathol 1996;148:889-896. [PubMed: 8774143]

Vanoye CG, Lossin C, Rhodes TH, George AL Jr. Single-channel properties of human NaV1.1 and mechanism of channel dysfunction in SCN1A-associated epilepsy. J Gen Physiol 2006;127:1-14. [PubMed: 16380441]

Waxman SG. Sodium channel blockers and axonal protection in neuroinflammatory disease. Brain 2005;128:5-6. [PubMed: 15596795]

Waxman SG. Axonal conduction and injury in multiple sclerosis: the role of sodium channels. Nat Rev Neurosci 2006;7:932-941. [PubMed: 17115075]

Waxman SG. Axonal dysfunction in chronic multiple sclerosis: Meltdown in the membrane. Ann Neurol. $2008 \mathrm{a}$

Waxman SG. Mechanisms of disease: sodium channels and neuroprotection in multiple sclerosis-current status. Nature clinical practice 2008b;4:159-169.

Waxman SG, Craner MJ, Black JA. Na+ channel expression along axons in multiple sclerosis and its models. Trends in pharmacological sciences 2004;25:584-591. [PubMed: 15491781]

Westenbroek RE, Noebels JL, Catterall WA. Elevated expression of type $\mathrm{II} \mathrm{Na}^{+}$channels in hypomyelinated axons of shiverer mouse brain. J Neurosci 1992;12:2259-2267. [PubMed: 1318958] 

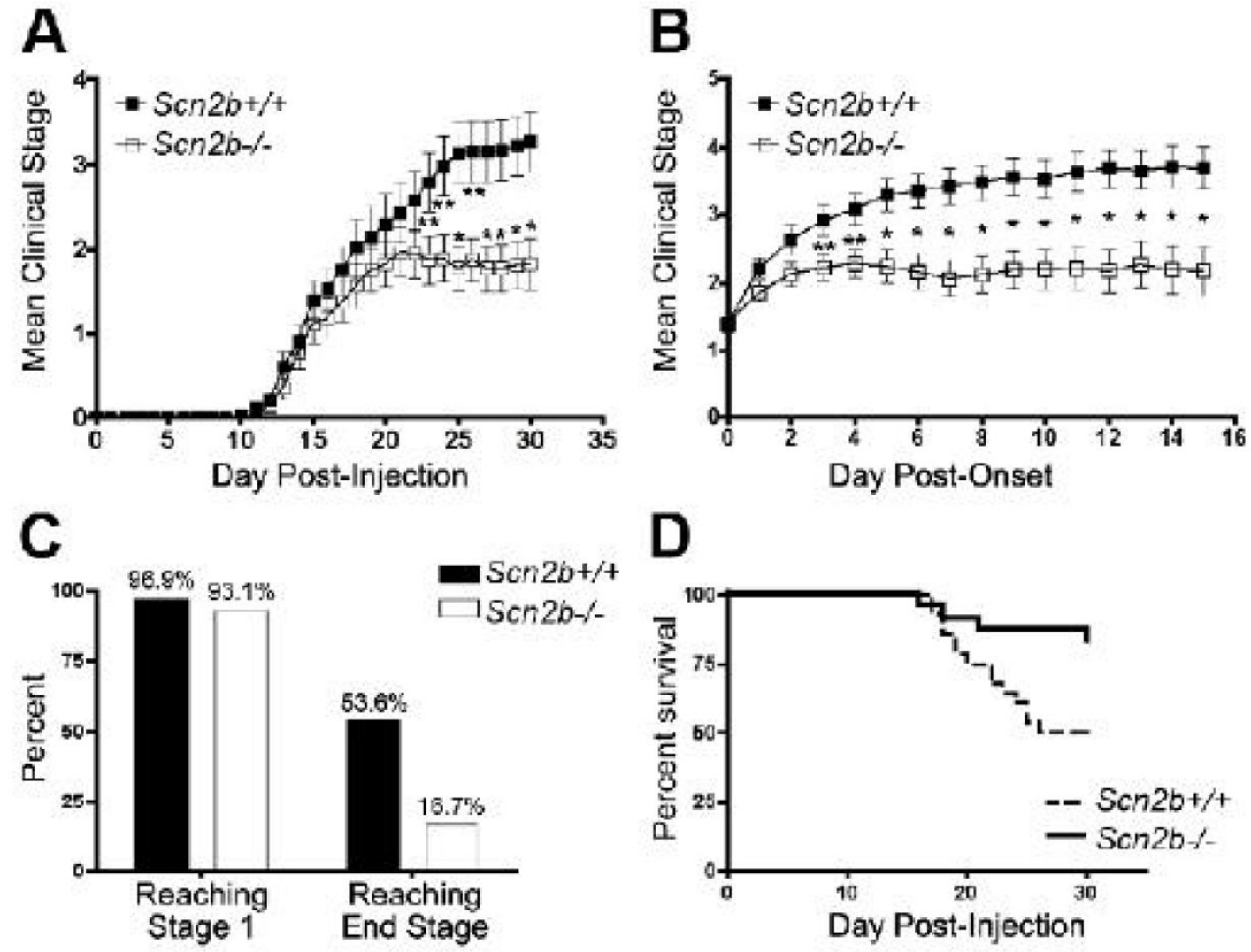

Fig. 1. $S c n 2 b^{-/-}$mice exhibit reduced symptom severity and lethality in EAE

Mean EAE clinical score post-injection of $\mathrm{MOG}_{35-55}$ peptide (A) and post-onset of clinical symptoms (B). Scn $2 b^{+/+}$(filled squares), $S c n 2 b^{-l-}$ (open squares). For post-onset data, day 0 represents the first day on which an individual animal displayed clinical symptoms. For (A) and (B), data points represent the average of clinical scores observed on that day for all animals ( \pm standard error). Mice reaching end stage were assigned a score of 5 for the remainder of the experimental time course and included in calculations. (C) Percent of mice reaching stage 1 clinical symptoms and end stage EAE (moribund or death). (D) Survival curve post-injection. $S c n 2 b^{+/+}$(dotted line), Scn $2 b^{-/-}$(solid line). Data represent combined observations from 5 independent experiments. * : $\mathrm{P}<0.005, * *: \mathrm{P}<0.05$. For A, $\mathbf{C}$ (stage 1$):(\mathrm{n}=32$ for $\operatorname{Scn} 2 b^{+/+}, \mathrm{n}=29$ for $\left.\operatorname{Scn} 2 b^{-/-}\right)$. For B, C (stage 2) : $\left(\mathrm{n}=31\right.$ for $\operatorname{Scn} 2 b^{+/+}, \mathrm{n}=27$ for $\left.\operatorname{Scn} 2 b^{-1-}\right)$. 



Fig. 2. $\operatorname{Scn} 2 b^{-1-}$ mice display decreased axonal loss, axonal degeneration, and demyelination in optic nerve in EAE

EAE was induced in $S c n 2 b^{+/+}$and $S c n 2 b^{-/-}$mice and optic nerve axons were isolated at 19 dpi. (A-D) Representative transmission electron micrographs of optic nerve cross-sections from control and EAE mice. (A) $S c n 2 b^{+/+}$and (B) $S c n 2 b^{-/-}$control tissue showing numerous, normally myelinated axons. (C) $S c n 2 b^{+/+}$tissue after EAE induction, displaying extensive axonal loss, grossly swollen and degenerating axons (arrows), and myelin debris (arrowhead). Oligodendrocyte (O). (D) $S c n 2 b^{-1-}$ tissue after EAE induction, displaying degenerating axon (arrow) and myelin debris (arrowhead) but a lesser extent of axonal loss. Scale bar $=2 \mu \mathrm{M}$. All micrographs at 7900x magnification. (E-H) Quantification of data obtained from micrographs. 
(E) Mean number of axons (intact + degenerating) per FOV. (F) Mean percentage of demyelinated axons (relative to total axon number for each image) per FOV. Axons ensheathed by zero, one, or two myelin wraps were counted. (G) Mean number of degenerating axons per FOV. (H) Mean percentage of degenerating axons (relative to total axon number for each image) per FOV. *: $\mathrm{P}<0.0001 . \mathrm{n}=156 \mathrm{FOV} S c n 2 b^{+/+}(\mathrm{EAE}), \mathrm{n}=158 \mathrm{FOV} \mathrm{Scn} 2 b^{+/+}$(control), $\mathrm{n}=162$ FOV Scn $2 b^{-/-}$(EAE and control). 
A
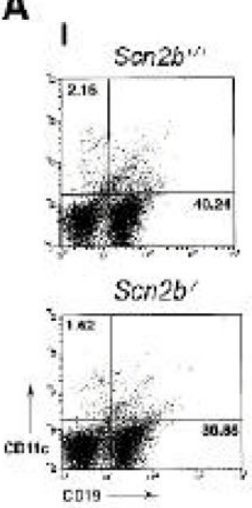

B

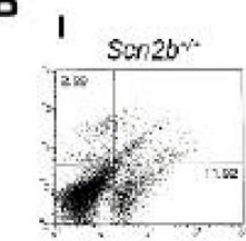

$\operatorname{sen} 2 b^{*}$

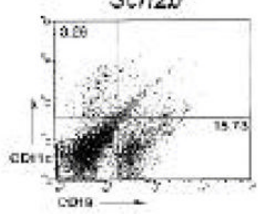

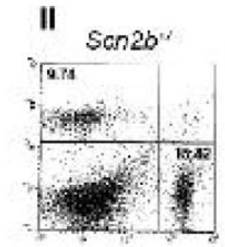
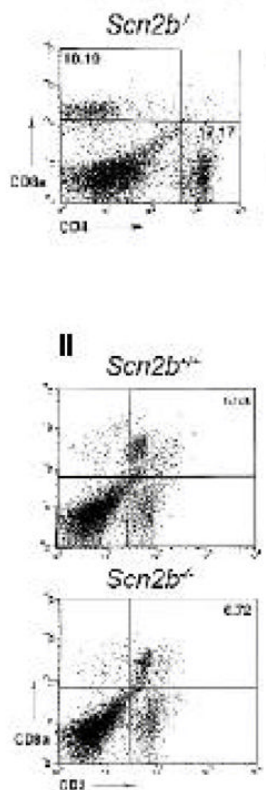

C

1234 RB
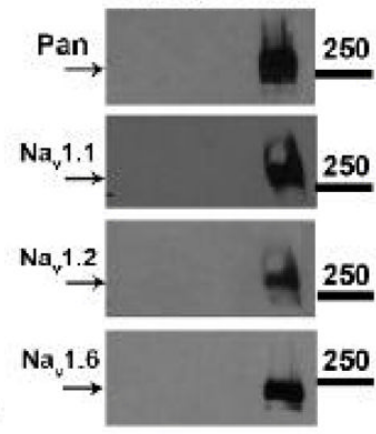

250
D

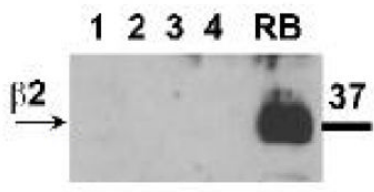

E

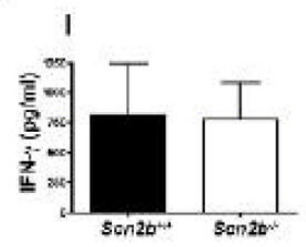

II

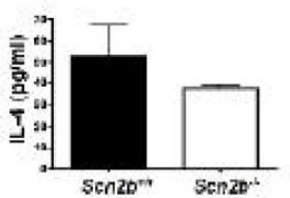

III

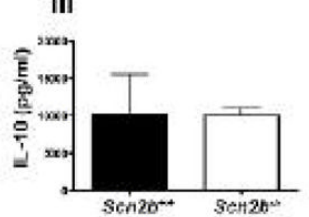

Fig. 3. The $S c n 2 b$ null mutation does not alter immune cell profiles or cytokine release under control or EAE conditions

$S c n 2 b^{+/+}$and $S c n 2 b^{-/-}$mice under control and EAE conditions display similar populations of peripheral immune cells. (A) Flow cytometry, naïve animals. Naïve $\operatorname{Scn} 2 b^{+/+}$(top) and $S c n 2 b^{-/-}$(bottom) mice display similar populations of immune cells. Representative dot plots are shown; quadrants are labeled with mean percentages $(\mathrm{n}=3)$. (I) CD11c (dendritic cell) and CD19 (B cell) populations. (II) CD8a and CD4 T cell populations. (B) Flow cytometry, EAE animals. $S c n 2 b^{+/+}$(top) and $S c n 2 b^{-/-}$(bottom) mice display similar populations of immune cells at 12 dpi. Cells were pooled from three spleens before single analysis. (I) CD11c (dendritic cell) and CD19 (B cell) populations. (II) CD8a T cell populations. (III) CD4 T cell populations. (C,D) Splenocytes do not express $\mathrm{Na}^{+}$channel proteins. Splenocytes from $\mathrm{Scn} 2 b^{-/-}$and $S c n 2 b^{+/+}$mice under naïve and EAE conditions were isolated. Equal aliquots of splenocyte homogenates or rat brain membranes (as a control) were analyzed using Western blotting. Lane 1: $S c n 2 b^{+/+}$control splenocytes, Lane 2: $S c n 2 b^{+/+}$EAE splenocytes, Lane 3: $S c n 2 b^{-/-}$control splenocytes, Lane 4: $S c n 2 b^{-1-}$ EAE splenocytes. Molecular weight markers are shown in kdal. (C) Probe: anti- $\beta 2$ antibody. Arrow shows immunoreactive Scn $2 b$ band. (D) Probe: anti$\mathrm{Na}_{\mathrm{v}} 1$ antibodies against Pan-Na ${ }^{+}$channel protein, $\mathrm{Na}_{\mathrm{v}} 1.1, \mathrm{Na}_{\mathrm{v}} 1.2$, or $\mathrm{Na}_{\mathrm{v}} 1.6$. (E) Cytokine release is similar in $S c n 2 b^{+/+}$and $S c n 2 b^{-/-}$splenocytes. Splenocytes from $S c n 2 b^{+/+}$and $\operatorname{Scn} 2 b^{-/-}$mice at 13 days post-induction displayed similar levels of antigen-stimulated cytokine release after $72 \mathrm{~h}$ in vitro following stimulation with $\mathrm{MOG}_{35-55}$ peptide. I: IFN- $\gamma$. II: IL-4. III: IL-10. 


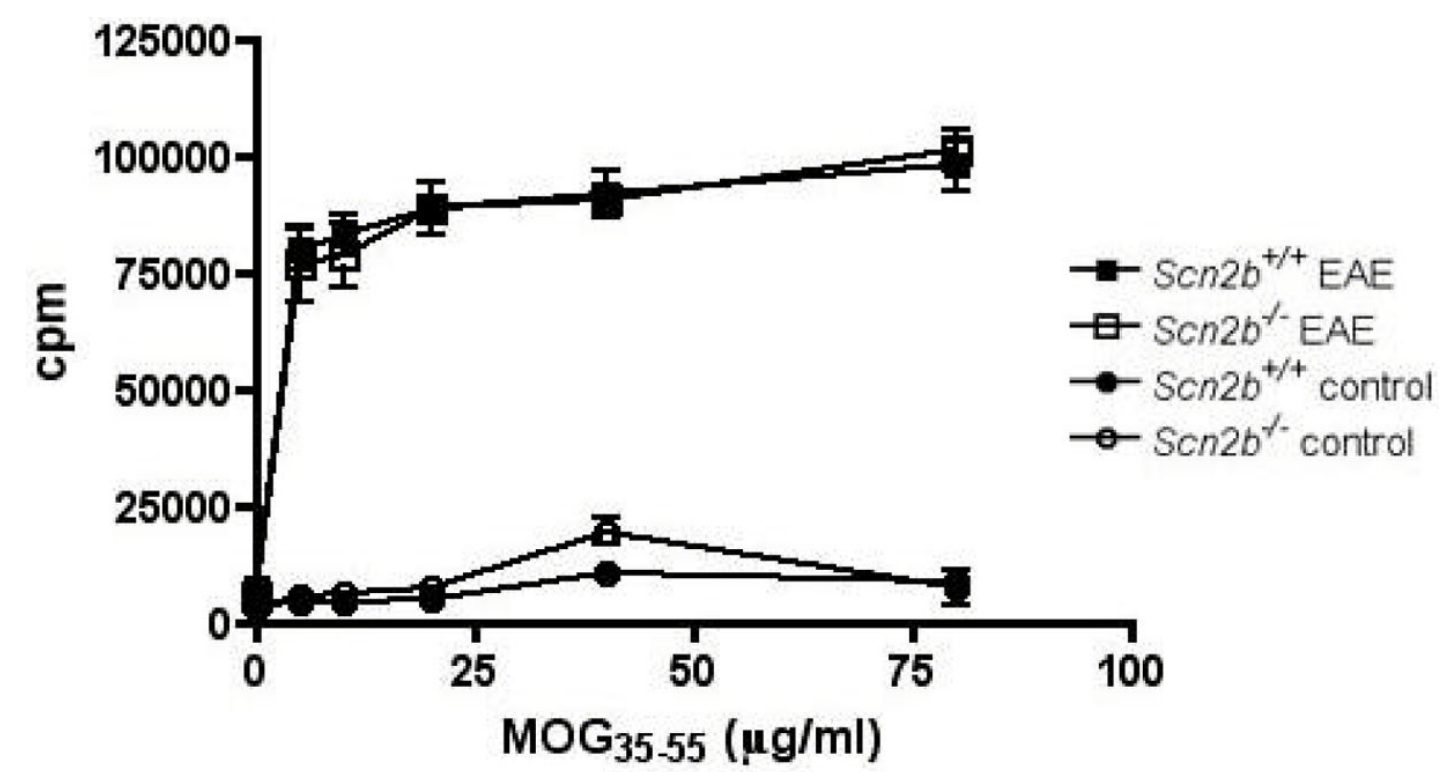

Fig. 4. T cell proliferation in $S c n 2 b^{+/+}$and $S c n 2 b^{-/-}$mice

T cells from $S c n 2 b^{+/+}$and $S c n 2 b^{-/-}$mice at 13 dpi in EAE display similar levels of proliferation in vitro in response to the presence of $\mathrm{MOG}_{35-55}$ peptide at varying concentrations. $\mathrm{T}$ cells from naïve mice do not display significant proliferation in response to the presence of peptide. No proliferation was observed in the absence of peptide in any group. $n=3$ for EAE animals, $\mathrm{n}=1$ for controls. 

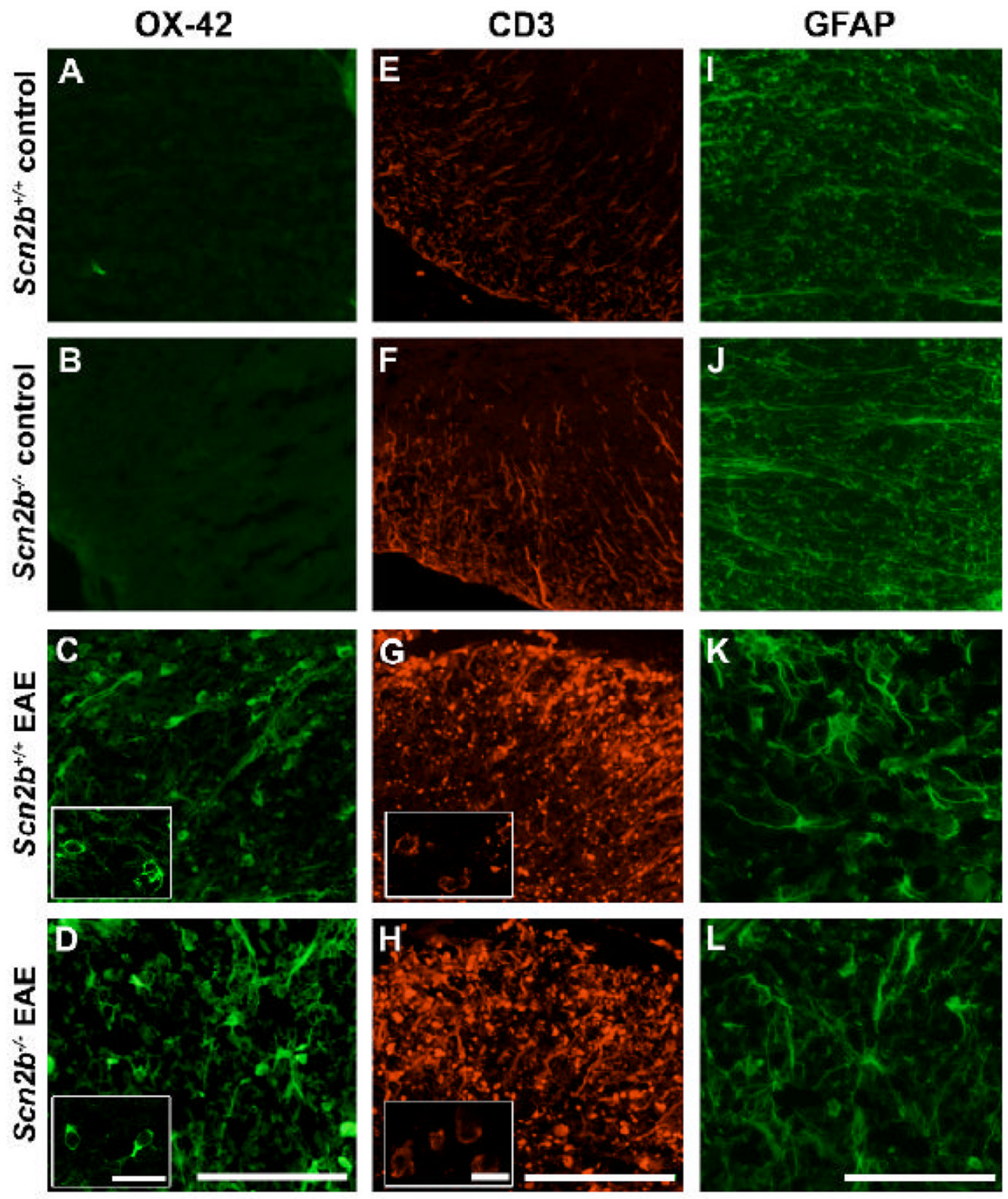

Fig. 5. Cellular infiltration into $S c n 2 b^{+/+}$and $S c n 2 b^{-/-}$spinal cord at 19 dpi in EAE. (A-D) $\operatorname{Scn} 2 b^{+/+}$and $S c n 2 b^{-/-}$mice display similar extents of microglial infiltration after induction of EAE and absence of infiltration in control tissue. A, B: $\operatorname{Scn} 2 b^{+/+}(\mathbf{A})$ and $S c n 2 b^{-1-}$ (B) control spinal cord sections, showing an absence of OX-42 immunopositive staining. C, D: $\operatorname{Scn} 2 b^{+/+}$(C) and Scn $2 b^{-/-}$(D) spinal cord cross-sections after EAE induction, displaying significant increases in microglial infiltration as observed by increased OX-42 (CD11b/c) immunofluorescence. Inset (in C, D) shows OX-42-positive cells with an amoeboid, activated morphology. Scale bar, $100 \mu \mathrm{m}$; inset $20 \mu \mathrm{m}$. (E-H) $S c n 2 b^{+/+}$and $\operatorname{Scn} 2 b^{-/-}$mice display similar extents of T cell infiltration after induction of EAE, and absence of infiltration in control tissue. $\mathbf{E}, \mathbf{F}: \operatorname{Scn} 2 b^{+/+}(\mathbf{E})$ and $S c n 2 b^{-/-}(\mathbf{F})$ control spinal cord sections, showing an absence of CD3- 
positive staining. G, H: $\operatorname{Scn} 2 b^{+/+}(\mathbf{G})$ and $S c n 2 b^{-/-}(\mathbf{H})$ spinal cord cross-sections after EAE induction, displaying significant increases in infiltration as observed by increased CD3 immunofluorescence. Inset (in $\mathbf{G}, \mathbf{H}$ ) shows CD3-positive cells. Scale bar, 200 $\mu \mathrm{m}$; inset $10 \mu \mathrm{m}$. (I-L) Increases in reactive astrocyte numbers in both $S c n 2 b^{+/+}$and $S c n 2 b^{-1-}$ mice following EAE induction as compared to controls. I, J: Scn $2 b^{+/+}$(I) and $S c n 2 b^{-/-}$(J) control spinal cord sections, showing GFAP-positive astrocytes with radial processes around tissue periphery. K, L: $S c n 2 b^{+/+}(\mathbf{K})$ and $S c n 2 b^{-/-}(\mathbf{L})$ spinal cord cross-sections after EAE induction. Increased numbers of GFAP-positive astrocytes with stellate morphology and astrocyte invasion to white matter is visible. Scale bar, $100 \mu \mathrm{m}$. 


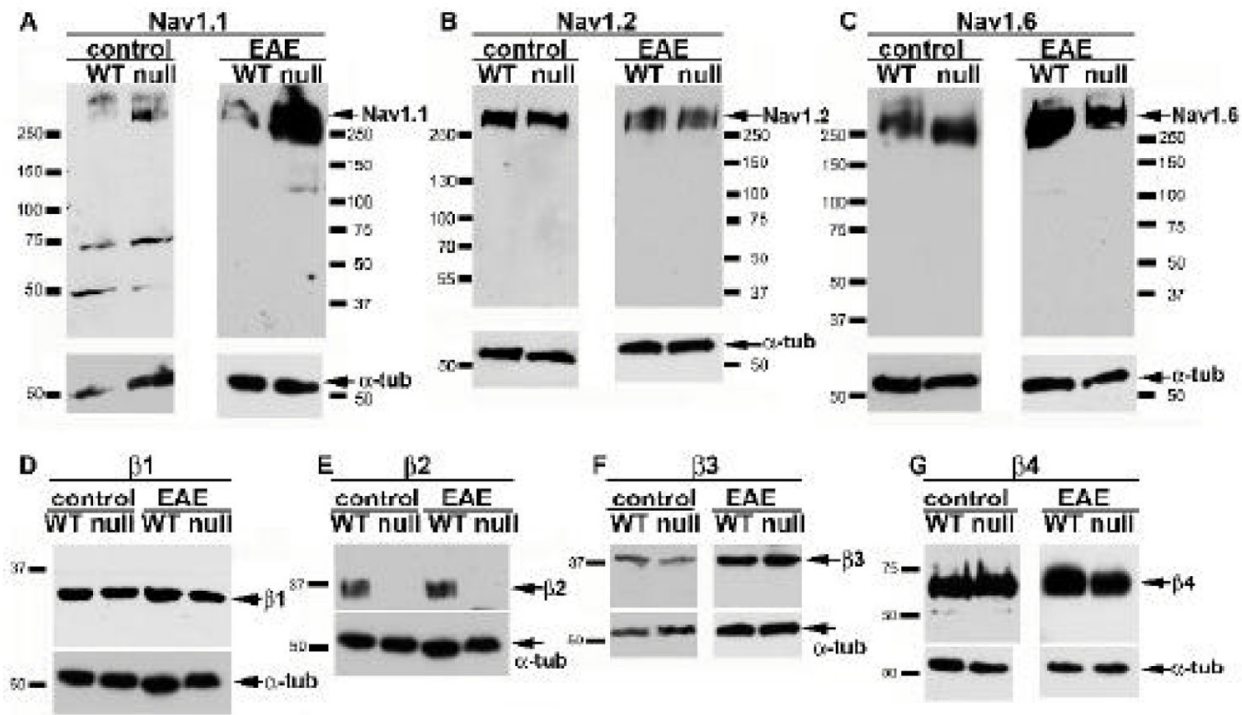

Fig. 6. Expression levels of $\mathrm{Na}^{+}$channel $\alpha$ and $\beta$ subunits in $S c n 2 b^{+/+}$and $S c n 2 b^{-/-}$brain

Western blots of mouse brain homogenates were probed with antibodies to $\mathrm{Na}_{\mathrm{v}} 1.1, \mathrm{Na}_{\mathrm{v}} 1.2$ or $\mathrm{Na}_{\mathrm{v}} 1.6$, or to $\beta 1, \beta 2, \beta 3$, or $\beta 4$. Samples were collected 15 dpi in EAE. Lanes were loaded with equal amounts of protein; blots were stripped and reprobed with anti- $\alpha$-tubulin as a loading control and this signal is shown at $\sim 50 \mathrm{kDa}$ in the bottom gel section in each panel. A: Anti$\mathrm{Na}_{\mathrm{v}}$ 1.1. B: Anti-Na 1 1.2. C: Anti-Na 1.6 . (D-G) $S c n 2 b^{+/+}$and $S c n 2 b^{-/-}$mice display no differences in expression levels of $\mathrm{Na}^{+}$channel $\beta$ subunits under control or EAE conditions. $\beta 2$ was absent in $S c n 2 b^{-/-}$brains. No difference in expression of $\beta 2$ was observed in $\operatorname{Scn} 2 b^{+/+}$tissue under control conditions vs. EAE conditions. D: Anti- $\beta 1$. E: Anti- $\beta 2$. F: Anti- $\beta 3$. G: Anti- $\beta 4$. 


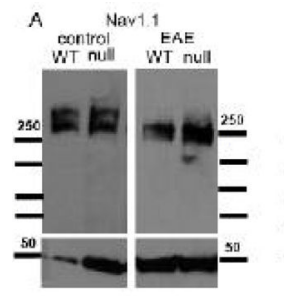

B Nav1.2
contral EAE
WT null WT WT null WT nu

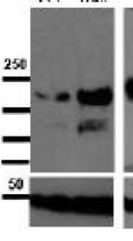

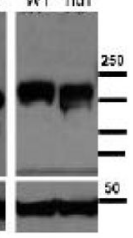

C Navis WT null WT null

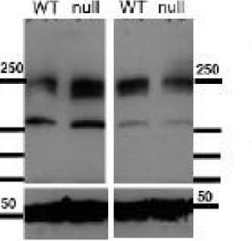
contral ${ }^{1 / 2}$ EAE WT null WT nill
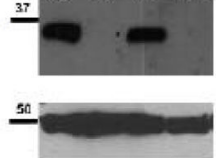

Fig. 7. Expression levels of $\mathrm{Na}^{+}$channel $\alpha$ and $\beta$ subunits in $\mathrm{Scn}_{2} \mathrm{~b}^{+/+}$and $\mathrm{Scn}_{2} \mathrm{~b}^{-/-}$spinal cord Western blots of mouse spinal cord homogenates were probed with antibodies to $\mathrm{Na}_{\mathrm{v}} 1.1$, $\mathrm{Na}_{\mathrm{v}} 1.2, \mathrm{Na}_{\mathrm{v}} 1.6$, or $\beta 2$. Blots were stripped and reprobed with anti- $\alpha$-tubulin as a loading control and this signal is shown at $\sim 50 \mathrm{kDa}$ in the bottom gel section in each panel. A: Anti- $\mathrm{Na}_{\mathrm{v}} 1.1$. B: Anti-Na 1 1.2. C: Anti-Na 1 1.6. D: $\beta 2$ was absent in $S c n 2 b^{-1-}$ tissues. No difference in expression of $\beta 2$ was observed in $S c n 2 b^{+/+}$tissue under control conditions vs. EAE conditions. 

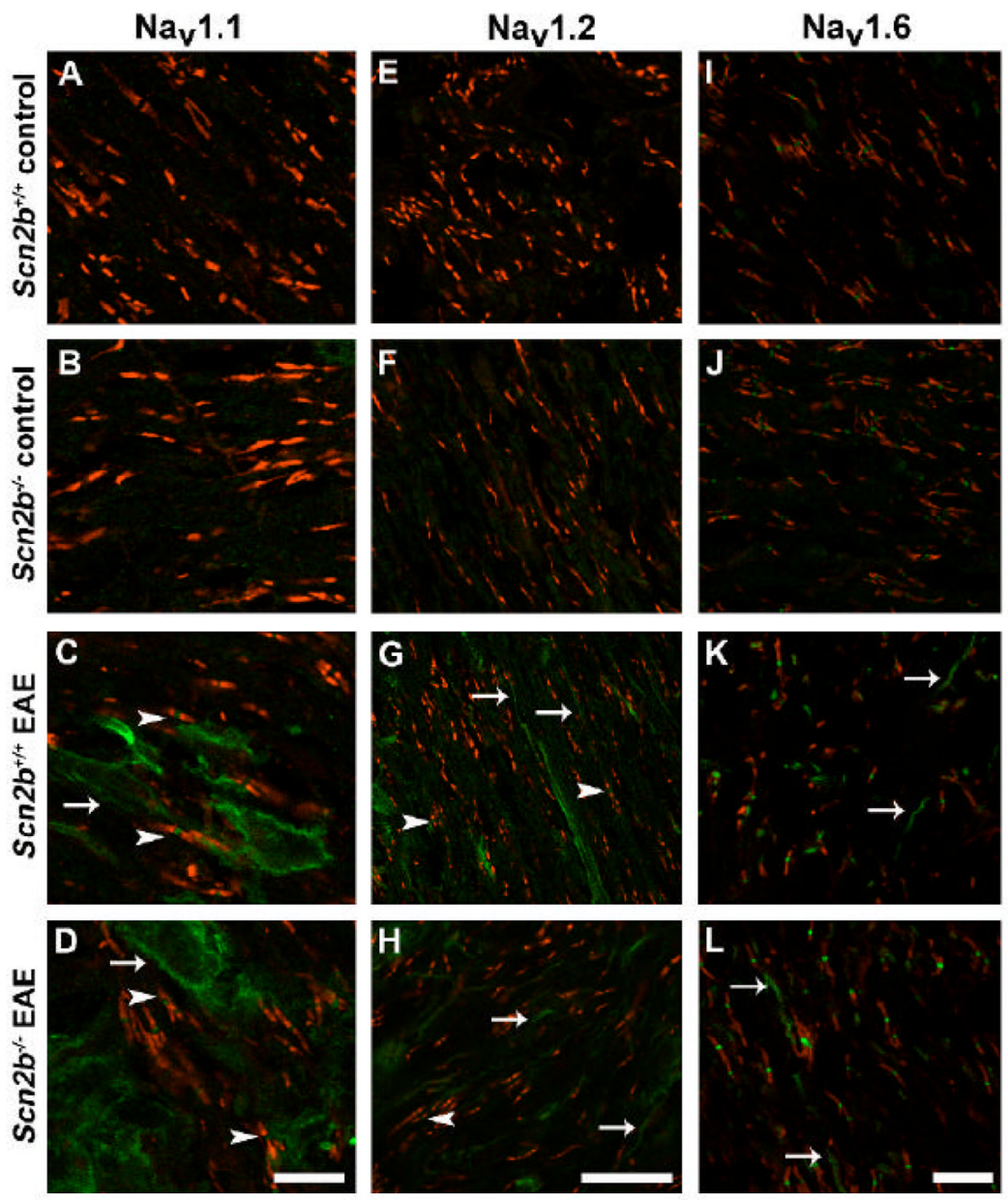

Fig. 8. Localization of $\mathrm{Na}^{+}$channel $\alpha$ subunits in optic nerve

$S c n 2 b^{+/+}$and $S c n 2 b^{-/-}$mice display alterations in localization of $\mathrm{Na}^{+}$channel $\alpha$ subunits after induction of EAE as compared to controls in longitudinal sections of optic nerve. (A-D)

$\mathrm{Na}_{\mathrm{v}} 1.1$ immunolocalization. A, B: $\operatorname{Scn} 2 b^{+/+}(\mathbf{A})$ and $\operatorname{Scn} 2 b^{-/-}$(B) control optic nerves show an absence of $\mathrm{Na}_{\mathrm{v}} 1.1$ at the nodal gap. C, D: $\operatorname{Scn} 2 b^{+/+}$(C) and $\operatorname{Scn} 2 b^{-/-}$(D) nerves after EAE induction display $\mathrm{Na}_{\mathrm{v}} 1.1$ immunofluorescence along axons as well as at some nodes of Ranvier. Scale bar, $10 \mu \mathrm{m}$. (E-H) $\mathrm{Na}_{\mathrm{v}} 1.2$ immunolocalization. E, F: $\operatorname{Scn} 2 b^{+/+}(\mathbf{E})$ and $\operatorname{Scn} 2 b^{-/-}(\mathbf{F})$ control optic nerves do not express $\mathrm{Na}_{\mathrm{v}} 1.2$. G, H: $\operatorname{Scn} 2 b^{+/+}(\mathbf{G})$ and $\operatorname{Scn} 2 b^{-/-}(\mathbf{H})$ optic nerves show diffuse immunofluorescence along demyelinated axons and at nodes. Scale bar, $20 \mu \mathrm{m}$. (I-L) $\mathrm{Na}_{\mathrm{v}} 1.6$ immunolocalization. I, J: Scn $2 b^{+/+}(\mathbf{I})$ and $\operatorname{Scn} 2 b^{-/-}$(J) control optic nerves contain clustered $\mathrm{Na}_{\mathrm{v}}$ 1.6. K, $\mathbf{L}: \operatorname{Scn} 2 b^{+/+}(\mathbf{K})$ and $S c n 2 b^{-/-}(\mathbf{L})$ optic nerves after EAE induction display $\mathrm{Na}_{\mathrm{v}} 1.6$ immunofluorescence at nodes of Ranvier as well as along demyelinated axons. Scale bar, $10 \mu \mathrm{m}$. 

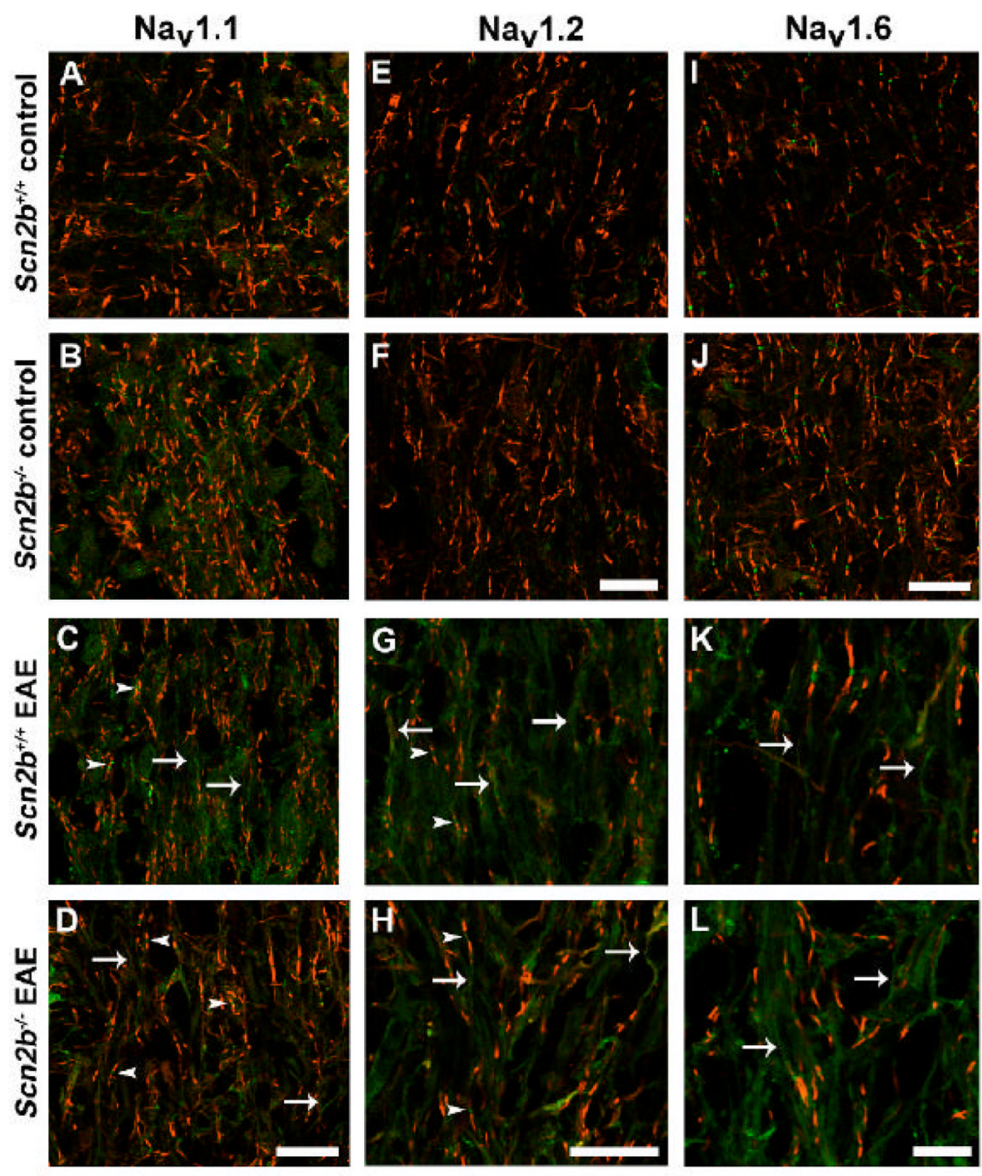

Fig. 9. Localization of $\mathrm{Na}^{+}$channel $\alpha$ subunits in spinal cord

$S c n 2 b^{+/+}$and $S c n 2 b^{-/-}$mice display alterations in localization of $\mathrm{Na}^{+}$channel $\alpha$ subunits after induction of EAE as compared to controls in longitudinal sections of spinal cord. (A-D)

$\mathrm{Na}_{\mathrm{v}} 1.1$ immunolocalization. A, B: $\operatorname{Scn} 2 b^{+/+}(\mathbf{A})$ and $S c n 2 b^{-/-}(\mathbf{B})$ control spinal cords express $\mathrm{Na}_{\mathrm{v}} 1.1$ at some nodes of Ranvier. C, D: $S c n 2 b^{+/+}(\mathbf{C})$ and $S c n 2 b^{-l-}$ (D) spinal cords after EAE induction display $\mathrm{Na}_{\mathrm{v}} 1.1$ immunofluorescence along axons as well as at some nodes of Ranvier. Scale bar, $20 \mu \mathrm{m}$. (E-H) $\mathrm{Na}_{\mathrm{v}} 1.2$ immunolocalization. E, F: Scn $2 b_{+/+}(\mathbf{E})$ and $S c n 2 b^{-1-}(\mathbf{F})$ control spinal cords express $\mathrm{Na}_{\mathrm{v}} 1.2$ at some nodes of Ranvier. Scale bar, $10 \mu \mathrm{m}$. G, $\mathbf{H}$ : $\operatorname{Scn} 2 b^{+/+}(\mathbf{G})$ and $\operatorname{Scn} 2 b^{-/-}(\mathbf{H})$ spinal cords show diffuse immunofluorescence along demyelinated axons and at nodes. Scale bar, $20 \mu \mathrm{m}$. (I-L) $\mathrm{Na}_{\mathrm{v}} 1.6$ immunolocalization. I, J: $S c n 2 b^{+/+}(\mathbf{I})$ and $S c n 2 b^{-/-}(\mathbf{J})$ control spinal cords contain clustered $\mathrm{Na}_{\mathrm{v}}$ 1.6. Scale bar, $20 \mu \mathrm{m}$. $\mathbf{K}, \mathbf{L}: \operatorname{Scn} 2 b^{+/+}(\mathbf{K})$ and $S c n 2 b^{-/-}(\mathbf{L})$ spinal cords after EAE induction display $\mathrm{Na}_{\mathrm{v}} 1.6$ immunofluorescence at nodes of Ranvier as well as along demyelinated axons. Scale bar, $10 \mu \mathrm{m}$. 